\title{
Trends in temperature extremes in selected growing cities of Mexico under a non-stationary climate
}

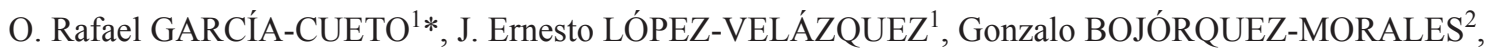 \\ Néstor SANTILLÁN-SOTO ${ }^{1}$ and David Enrique FLORES-JIMÉNEZ ${ }^{1}$
}

\author{
${ }^{1}$ Instituto de Ingeniería, Universidad Autónoma de Baja California, Blvd. Benito Juárez y C. de la Normal, Col. \\ Insurgentes Este, 21280 Mexicali, Baja California, México. \\ ${ }^{2}$ Facultad de Arquitectura y Diseño, Universidad Autónoma de Baja California, Churubusco e Ignacio López Rayón, \\ Col. Insurgentes Este, 21280 Mexicali, Baja California, México. \\ *Corresponding author; email: rafaelcueto@uabc.edu.mx
}

Received: October 7, 2019; accepted: June 10, 2020

\begin{abstract}
RESUMEN
México es un país vulnerable a los eventos climáticos extremos; sin embargo, el impacto no es uniforme en todo el territorio, por lo que se analizan y modelan las temperaturas extremas de 12 ciudades de México con la suposición de que existe un clima no estacionario en todas las regiones del país. A partir de la base climatológica disponible de temperaturas máximas y temperaturas mínimas, se estimó una tendencia temporal con las pruebas no paramétricas de Mann-Kendall y el método de pendiente de Sen, y se utilizó la distribución generalizada de valores extremos (GEV) para modelar ambas temperaturas. Para evaluar la fortaleza de los modelos propuestos con la incorporación de una covariable, se utilizaron tanto la prueba de razón de verosimilitud como los criterios de información de Akaike y de Bayes, y se estimaron los niveles de retorno para escenarios temporales futuros. Se detectó una tendencia al calentamiento urbano, tanto con las pruebas no paramétricas como con la distribución GEV, aunque con comportamiento heterogéneo. En la serie de temperatura máxima, la mitad de las ciudades analizadas se mostró no estacionaria; de éstas, la ciudad de Guadalajara, situada en el centro-occidente del país, presentó tendencia negativa. En el caso de las temperaturas mínimas la tendencia fue más uniforme: $90 \%$ de las ciudades se mostraron no estacionarias con tendencia positiva y sólo el 10\% (una zona urbana al oriente de la zona metropolitana del Valle de México [Milpa Alta] y una ciudad costera del Golfo de México [Veracruz]) mostraron una serie estacionaria. Se concluye que los periodos de retorno de extremos térmicos estimados en un clima cambiante varían temporalmente, por lo que la modelación estadística debe tomar en cuenta ese comportamiento en razón de su importancia para valoraciones de riesgos y propósitos de adaptación.
\end{abstract}

\begin{abstract}
Mexico is vulnerable to extreme climatic events; however, their impact is not uniform in all the country. This study presents an analysis of extreme temperatures in 12 Mexican cities, modeled under the assumption of a non-stationary climate. Temporal trends were estimated from an available climatological base of maximum and minimum temperatures with the non-parametric tests of Mann-Kendall and Sen's slope method, and a generalized extreme value (GEV) distribution was used to model both temperatures. A likelihood ratio test and Akaike and Bayesian information criteria were used to evaluate the optimal model choice with incorporation of a covariate. Using the best model, return levels and confidence intervals for future scenarios were estimated. A trend towards urban warming was detected from both the non-parametric tests and the GEV distribution, although with heterogeneous behavior. In the series of the maximum temperatures, half of the cities analyzed were non-stationary, and of those, the city of Guadalajara, located in the center-west of the country had a negative trend. The trend for minimum temperatures was more uniform, as $90 \%$ of the cities
\end{abstract}


were non-stationary with a positive trend, and only $10 \%$, in an urban area to the east of the metropolitan area of the Valley of Mexico (Milpa Alta) and a coastal city of the Gulf of Mexico (Veracruz), showed stationary series. It is therefore concluded that return periods of thermal extremes estimated in a changing climate temporarily showed a significant variation, so statistical modeling must consider this behavior due to its importance for risk assessments and adaptation purposes.

Keywords: extreme temperatures, non-stationary climate, generalized extreme value distribution, return periods, cities of Mexico.

\section{Introduction}

Extreme climate events (ECE) must be periodically monitored and analyzed in detail, due to their role as high impact agents on society, environment, and ecosystems. An extreme climatic or meteorological event refers to the occurrence of a climatic or meteorological variable which value is above or below a threshold that is close to the upper (or lower) limits of the range of observed values of the variable (Seneviratne et al., 2012). ECE are important because of their impacts, but they are difficult to quantify statistically, as they are infrequent and occur at multiple scales (Palmer and Räisänen, 2002). The definitions of "rare" vary, but an ECE would normally be as rare as, or rarer than, the 10th or 90th percentile of the observed probability density function.

It is likely that different ECE affect specific regions and increases in their frequency and intensity have been detected in several regions of the world (Brown et al., 2008; Almazroui et al., 2014; Chen et al., 2015; Wypych et al., 2017; Caloiero, 2017). It is expected that these ECE will intensify in the future in response to global climate changes caused by the emission of greenhouse gases (Beniston et al., 2007; Gao et al., 2012; Lau and Nath, 2012; Easterling et al., 2016; Grotjahn et al., 2016; Schoof and Robeson, 2016).

There are basically two fundamental approaches to study ECE: global circulation models (GCMs), and statistical models using the extreme value theory (EVT). Contemporary GCMs, such as those used for the 5th Coupled Model Intercomparison Project (Taylor et al., 2012) are a key component of regional climate change projections, but their limited spatial resolution reduces their utility in estimating local or regional extremes without substantial post-processing (Schoof and Robeson, 2016). On the other hand, the central issue of EVT is the modeling of extreme events, and the main purpose of this theory is to provide asymptotic models for the distribution tails (Furió and Meneu, 2011). Therefore, EVT aims at deriving a probability distribution of events at the far end of the upper or lower ranges of the probability distributions (Coles, 2001); its main advantage is that it allows for estimating and analyzing the probability of occurrence of events that are outside of the observed data range (Raggad, 2018).

For these reasons, EVT is the approach that has been chosen in this research due to its wide applicability in different fields that are related to extreme weather and climate events and their impact: ecology (Moritz, 1997; Meehl et al., 2000; Dixon et al., 2005; Katz et al., 2005; Jentsch et al., 2007; Burgman et al., 2012); extreme temperatures and heat waves (Meehl and Tebaldi, 2004; Della-Marta et al., 2007; Parey et al., 2007; García-Cueto et al., 2010; Waylen et al., 2012; Tanarhte et al., 2015; Liu et al., 2015; Shen et al., 2016); extreme rainfall (Katz et al., 2002; Koutsoyiannis, 2004; Friederichs, 2010; Papalexiou and Koutsoyiannis, 2013; Kim et al., 2015; Boucefiane and Meddi, 2019); and damages to the communities that affect agroecosystems through changes in soil moisture and evapotranspiration rates (Miralles et al., 2014; Whan et al., 2015; Guan et al., 2015; Hatfield and Prueger, 2015).

Changes in extremes of temperature and precipitation have been evaluated in different regions of the world. However, until the Fourth Assessment Report of the Intergovernmental Panel on Climate Change (Trenberth et al., 2007), the cities had been treated as "noise-generating" entities in globally studied climatic signals. In the Fifth Assessment Report of the Intergovernmental Panel on Climate Change (IPCC, 2013), a special chapter was dedicated to the subject of cities, and their role in climate change. This is not surprising, as although cities are very important contributors to social and economic well-being, they require an uninterrupted source of energy for 
all their activities. Cities consume approximately $75 \%$ of global primary energy and emit between 50 $60 \%$ of the greenhouse gases (GHG) on the planet (Rosenzweig et al., 2011). This figure can be raised to $80 \%$ when indirect emissions generated by inhabitants of the cities are included (UN-Habitat, 2011; Kraussmann et al., 2017). Thus, cities promote global warming, and contribute to an increase in average surface temperature at the planetary level.

In addition to the global effects of GHG, the worldwide upward trend of urban growth must be considered, both in population and in its areal extension. This growth has generated environmental problems, not only air pollution and solid waste, but also those concerning a different environmental product, such as the genesis of an urban climate. In particular, the main connotation of urban climate is the formation of an urban heat island, which in turn requires additional water and energy to maintain thermal comfort through air-conditioned spaces (Coutts et al., 2012; Wang et al., 2016; de Munck et al., 2018, Skelhorn et al., 2018). Thus, cities that are already particularly vulnerable to ECE caused by global climate change must now also consider the effects caused by local climate change. Therefore, it can be inferred that because a city is the geographical space that brings together a majority of the population and provision of services, it will be where the greatest vulnerabilities associated with the impacts of climate change manifest themselves (UN-Habitat, 2011).

In Mexico approximately three out of four people (72.3\%) live in cities according to Fundación Centro de Investigación y Documentación de la Casa and Sociedad Hipotecaria Federal (CIDOC-SHF, 2011). This percentage is expected to increase in the medium term, as according to projections of the National Population Council the number of people in 384 localities of the National Urban System will increase by 16.6 million (from 82.6 million in 2010 to 99.3 million in 2030) as a result of an annual average growth rate of $0.92 \%$ (Hernández et al., 2014). The urban proportion of the national population will increase to $77.9 \%$ (18.1 million new urban inhabitants). This trend of the geographic dynamics of cities is inequitable with low levels of quality of life and urban sustainability, and not all cities have the same development potential. Thus, the challenges in facing climatic risks such as heat waves and floods will be massive if quantitative scientific studies are not carried out.

Very little research has been conducted in Mexico on extreme climate values in urban environments (Magaña et al. 2003, 2012; Cavazos and Rivas, 2004; Ríos-Alejandro, 2011; García-Cueto et al., 2013, 2014, 2018; Martínez-Austria and Bandala, 2017). This can be explained by a limited access to measured climate data, limitations in the geographical coverage of the networks of stations, and interruptions in climate series due to missing data. In view of this and given the quantitative uncertainty of the climate extremes mentioned at the urban level and their great importance for the assessment of risks and adaptation proposals, this study selects some cities in Mexico with important increases in population and in areal extension, which have recently been affectated by ECE.

Thus, this study has three main objectives: (a) to detect thermal behavior in some growing cities of Mexico, (b) to model extreme temperatures through the EVT, and (c) to make projections of return levels for extreme temperatures in a future changing climate.

This paper is organized as follows: section 2 presents the climatology of extreme values in Mexico; section 3 presents the study area and the climate data, and section 4 provides a theoretical outline of the methodology. The results and discussion are presented in section 5 . In section 6 , conclusions are drawn.

\section{Climatology of extreme temperature values of Mexico}

Figures 1 and 2 show the 10th and 90th percentiles of minimum and maximum temperatures, respectively (Cavazos et al., 2013), for the period 1961-2000; the methodology used in these figures is described in Colorado-Ruiz et al. (2018). According to extreme climate indices derived from reliability ensemble averaging (REA) (Fig. 1), the coldest winters and their 10th percentile (P10) during the winter months of December, January, and February (DJF) for Mexico are characterized by minimum temperatures below $0{ }^{\circ} \mathrm{C}$ in the highlands of the Sierra Madre Occidental and the Mexican High Plateau, and between 0 and $5{ }^{\circ} \mathrm{C}$ in much of northern Mexico. Figure 2 shows that the extreme values of the 90th percentile (P90) of the 


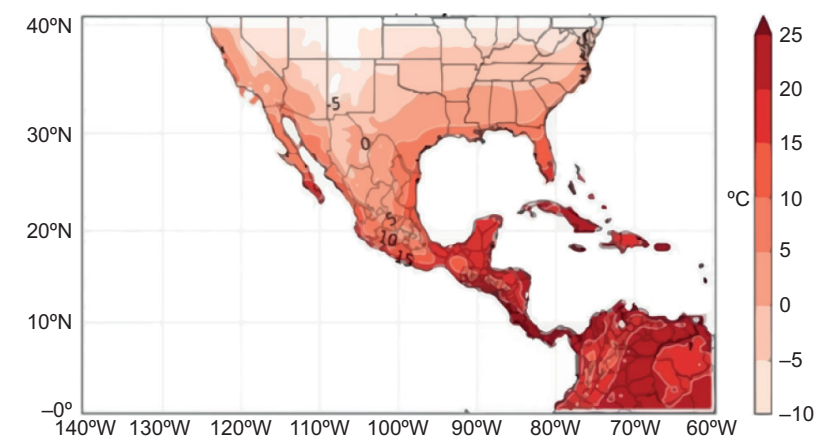

Fig. 1. Thresholds of $\mathrm{P} 10$ of minimum temperature for winter, obtained with the ensemble of the Reliability Ensemble Averaging (REA) for 1961-2000 (Cavazos et al., 2013).

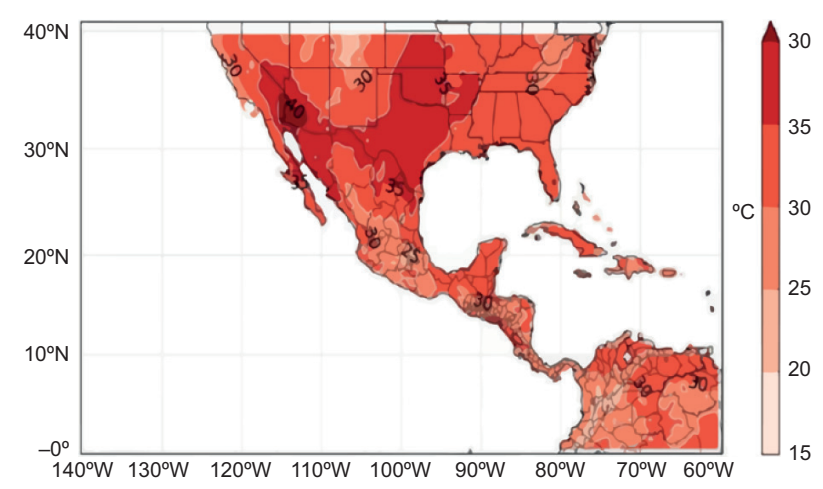

Fig. 2. Thresholds of $\mathrm{P} 90$ of maximum temperature for summer, obtained with the ensemble of the Reliability Ensemble Averaging (REA) for 1961-2000 (Cavazos et al., 2013).

maximum temperatures during the summer months of June, July, and August (JJA) expand the area covered by the isotherms of 25 and $40{ }^{\circ} \mathrm{C}$ to a narrower strip in the border region. This region of semiarid climate is the most extreme in Mexico; therefore, it is the most susceptible to negative impacts caused by increases in temperature.

The projected climate changes at a national level (Cavazos et al., 2013) agree with those obtained globally (Alexander et al., 2006; Caesar et al., 2011; Song et al., 2014). Regarding those related to the increase in the frequency of heat days, heatwaves and variability in precipitation will exacerbate problems related to natural and human systems (Ummenhofer and Meehl, 2017). If we analyze the 10th and 90th percentiles of extreme temperatures at the national level, there is a notable lack of reliable and timely information at the regional and urban levels for risk assessment, which justifies the study carried out herein.

\section{Data and study area}

A digital historical collection of daily temperature data for several cities in Mexico was possible using information from climatological stations operated by the Servicio Meteorológico Nacional (SMN, National Weather Service). Unfortunately, the selection of urban areas of interest faced some limitations, as not all climate stations have the same record length, and none had a strict data quality control. Based on a previous analysis of the growth of some cities in Mexico and the occurrence of climatic events that have affected them in important ways, 21 cities were selected in the first instance. However, an analysis of the quality of climate information limited the study to only 12 cities. These cities are heterogeneously distributed in the country because, as mentioned above, they were selected for their population growth and urban development. Data quality control was carried out for the daily information for each city, consisting of the following synthetic process.

The SMN database from the Climate Computing Project (CLICOM) was extracted in the .csv format, using Matlab and RClimdex software. The climatic information was explored, and quality control was performed for the original database. The daily meteorological values of maximum temperature (TXX) and minimum temperature (TNN) were selected with a computation routine; at the same time, a continuity of the time series was sought by adding missing dates and values, if possible, and adding a -99.99 label for missing data. Subsequently, the database was imported into the RClimdex program (Zhang and Yang, 2004), ensuring the internal and temporal consistency of the daily climatological information. This quality control validated the following: (1) internal coherence, by verifying that the maximum temperature was always greater than the minimum temperature; (2) identification of atypical values and changes in the seasonal cycle or variability of the data through visual inspection of the time series of TXX and TNN, and (3) identification of values located more than four standard deviations $(\sigma)$ from the mean as outliers and possible 
errors. Finally, outliers were verified individually to determine if they had been caused by an atypical event or if the measurement was incorrect and had to be discarded.

Temporal homogeneity of the data was then evaluated using the RHtest V3 software (Wang and Feng, 2010) to identify abrupt jumps or change-points. This homogeneity test is based on a two-phase regression model with a linear trend for the entire series, applied to selected series for each of the cities.

The final selection included the following cities and/or intra-urban regions for the detailed analysis of extreme temperatures: Aguascalientes, Mexicali, Tijuana, Tuxtla Gutiérrez, Mexico City (with analysis of the climatological stations of Úrsula Coapa, Gran Canal, and Milpa Alta), León, Guadalajara, Monterrey, Puebla, Tlaxcala, Veracruz and the metropolitan area of the Valley of Mexico, including the urban areas of Toluca, Aculco and Chapingo (Table I). Their locations are presented in Figure 3 and, as can be seen, the analysis includes cities distributed in central Mexico (18-25 $\mathrm{N}$ latitude), a city in southeastern Mexico (Tuxtla Gutiérrez), another in northeastern Mexico (Monterrey), and two more in northwestern Mexico (Tijuana and Mexicali).

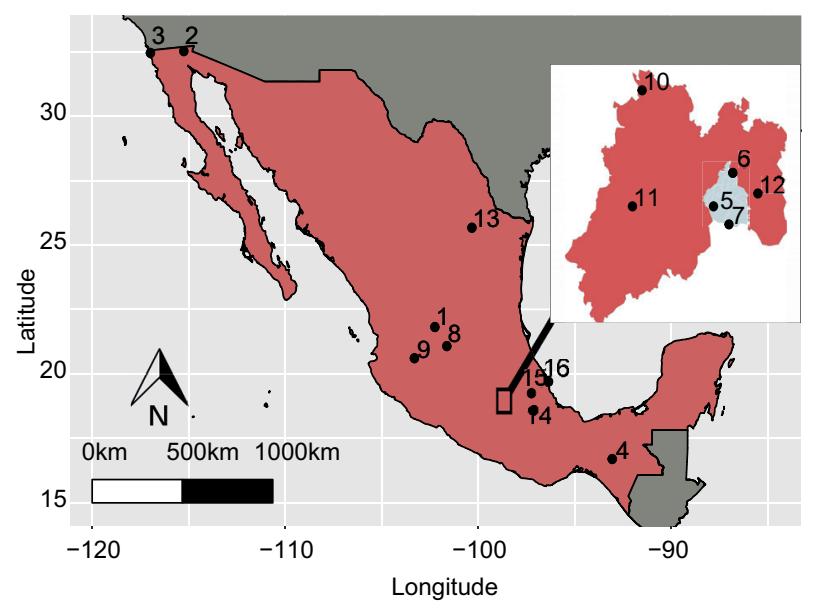

Fig. 3. Locations of intra-urban cities or regions according to Table I.

Table I. City or urban region, climatological station number, elevation, period of useful data, historical values of extreme maximum temperature, and extreme minimum temperature.

\begin{tabular}{llccrrr}
\hline ID & City or urban region & $\begin{array}{c}\text { Climatological } \\
\text { station number }^{\mathrm{a}}\end{array}$ & $\begin{array}{c}\text { Elevation } \\
(\mathrm{mas})\end{array}$ & Period & $\begin{array}{r}\mathrm{TXX} \\
\left({ }^{\circ} \mathrm{C}\right)\end{array}$ & $\begin{array}{r}\mathrm{TNN} \\
\left({ }^{\circ} \mathrm{C}\right)\end{array}$ \\
\hline 1 & Aguascalientes & 01030 & 1889 & $1950-2015$ & 40.0 & -6.0 \\
2 & Mexicali & 02033 & 4 & $1950-2012$ & 52.0 & -7.0 \\
3 & Tijuana & 02038 & 120 & $1950-2012$ & 45.0 & 0.0 \\
4 & Tuxtla Gutiérrez & 07165 & 570 & $1980-2010$ & 42.0 & 7.1 \\
5 & Úrsula Coapa, CDMX & 09014 & 2256 & $1971-2013$ & 34.5 & -3.0 \\
6 & Gran Canal, CDMX & 09029 & 2239 & $1952-2008$ & 38.5 & -7.5 \\
7 & Milpa Alta, CDMX & 09032 & 2420 & $1963-2012$ & 34.0 & -2.5 \\
8 & León & 11095 & 1828 & $1959-2014$ & 39.5 & -2.5 \\
9 & Guadalajara & 14066 & 1550 & $1957-2013$ & 47.0 & -1.5 \\
10 & Aculco, ZMVM & 15002 & 2490 & $1970-2011$ & 32.0 & -5.0 \\
11 & Toluca, ZMVM & 15126 & 2726 & $1974-2009$ & 33.6 & -10.0 \\
12 & Chapingo, ZMVM & 15170 & 2250 & $1954-2010$ & 37.5 & -8.5 \\
13 & Monterrey & 19049 & 495 & $1949-2009$ & 48.0 & -7.5 \\
14 & Puebla & 21035 & 2122 & $1955-2013$ & 36.5 & -6.0 \\
15 & Tlaxcala & 29030 & 2230 & $1969-2013$ & 39.2 & -7.4 \\
16 & Veracruz & 30192 & 16 & $1930-2014$ & 42.7 & 7.9 \\
\hline
\end{tabular}

${ }^{\mathrm{a}}$ Climatological station number refers to the key that the National Weather Service (SMN) of Mexico manages in its files.

TXX: extreme maximum temperature; TNN: extreme minimum temperature; CDMX: Mexico City; ZMVM: metropolitan area of the Valley of Mexico. 
Our study focused on ECE using a parametric non-stationary generalized extreme value (GEV) distribution model, which tacitly assumes that extreme events are changing over time as climate changes. Instead of the climate change indices used in García-Cueto et al. (2018), the current study directly applies extreme temperature values. In addition, the non-stationary GEV model is applied to investigate how the return levels of extreme temperatures might change in the future.

It is worth mentioning that for the city of Mexicali, due to the importance of extreme temperatures for human comfort and energy consumption for use in air conditioning, other studies have been carried out (García-Cueto et al., 2010, 2013). Unlike current research, in García-Cueto et al. (2010) warm days were modeled with the GEV and the maximum temperature was included as a covariate, without performing a temporal trend analysis of extreme temperatures. Their difference with respect to García-Cueto et al. (2013) is that the trends of extreme temperatures and their return periods are updated with a methodological process that requires a re-parameterization of the GEV model, which gives greater reliability in its estimation.

\section{Methodology}

In this section we present the techniques used for trend analysis and a brief review of the GEV distribution, to provide a basis for the modeling of extreme temperature events. As described in section 1 , the GEV distribution is used to model extremes in atmospheric science and in many other scientific fields. Using the trends of annual temperature series, we describe the non-stationary models, the criteria for deciding which GEV model to use, the estimation of the parameters of the GEV distribution, and the return levels.

\subsection{Trend analysis}

The detections of monotonic trends of increase or decrease in TXX and TNN in a time series were analyzed using the Mann-Kendall non-parametric test (Mann, 1945; Kendall, 1975) and Sen's method for slope estimates (Sen, 1968). The Mann-Kendall test is based on ranges and has been found to be an excellent tool for detecting trends in climatic applications (Burn and Hag Elnur, 2002; Mugume et al., 2016). One of the advantages of this test is that the data does not need to be adjusted to any distribution. The second advantage of this test is its low sensitivity to sudden breaks owing to non-homogeneous time series, extreme values (outliers), and non-linear trends (Helsel and Hirsch, 1992; Tabari et al., 2011). Given its robustness, the Mann-Kendall test has become very popular in evaluating trends in environmental data and allows adequate comparisons across regions (Fengjin and Lianchun, 2011; Qiang et al., 2011; Wang et al., 2013; Dumitrescu et al., 2015; Ongoma et al., 2016). Sen's method uses a linear model to estimate the slope of a trend, and the variance of the residuals must be constant over time (Salmi et al., 2002). Many studies (Taxak et al., 2014; Caloiero, 2017; García-Cueto et al., 2018; Raggad, 2018, among others) have described these methods explicitly.

\subsection{Generalized extreme values (GEV) stationary distribution}

The general framework of this study is a statistical EVT. The EVT aims to characterize rare events by describing the tails of the underlying distribution. The EVT concerns the asymptotic stochastic behavior of the extreme order statistics of a random sample, such as the maximum and minimum values of identically distributed independent random variables (Coles, 2001).

The Fisher-Tippett theorem (1928) states that if the distribution of the normalized maximum of a sequence of random variables converges, it always converges to the GEV distribution, independently of the underlying distribution. In this regard, let $X_{1}, \ldots$, $X_{\mathrm{n}}$ be a sequence of identically distributed independent random variables with a common distribution function $F$; the maximum sample, $M_{\mathrm{n}}$, with $n$ being the size of the block, is defined as $M_{\mathrm{n}}=\max \left\{X_{1}\right.$, $\left.X_{2}, \ldots, X_{\mathrm{n}}\right\} . X_{\mathrm{i}}$ usually represents the maximum (or minimum) values measured on a regular time scale or blocks of time, so $M_{\mathrm{n}}$ represents the extreme values of the process in $n$ units of observation time. The blocks of data in this study are sequences of observations having the length of a year, i.e., the approach uses the maximum and minimum values per annual blocks of temperature.

For these data, the distributions of $M_{\mathrm{n}}$ according to the EVT can be modelled as blocks of identically 
distributed extreme values with a GEV distribution as defined by Eq. (1), with a cumulative distribution function with three parameters given by (Coles, 2001):

$G(z ; \mu, \sigma, \xi)=\exp \left[-\{1+\xi(z-\mu) / \sigma\}^{-1 / \xi}\right]$

This distribution is defined on the set $\{z: 1+\xi(z-$ $\mu) / \sigma>0\}$. Here, $\mu$ is the location parameter $(-\infty<\mu<$ $\infty), \sigma$ is the scale parameter $(\sigma>0)$, and $\xi$ is the shape parameter $(-\infty<\xi<\infty)$ that determines the nature of the behavior of the tail of the maximum distribution. The justification for the GEV distribution arises from an asymptotic argument.

The GEV distribution combines the three possible limiting distributions on extreme values in sample data in a single expression. It is a family of continuous probability distributions developed to combine the three distributions of extreme values: Gumbel $(\xi=0)$, Fréchet $(\xi>0)$, and Weibull $(\xi<0)$, or distributions of extreme values types I, II, and III, respectively. Each of the three types of distributions has distinct forms of behavior in the tail. The Weibull is bounded above, meaning that there is a finite value which the maximum cannot exceed. The Gumbel distribution yields a light tail, meaning that although the maximum can take on infinitely high values, the probability of obtaining such levels becomes exponentially small. The Fréchet distribution has a heavy tail and decays polynomially, so that higher values of the maximum are obtained with greater probability, as would be the case with a lighter tail (Gilleland and Katz, 2006). The flexibility of the GEV in describing all three types of tail behavior in a single family greatly simplifies the statistical implementation.

\subsection{GEV non-stationary distribution}

As we will see later, the extreme temperatures in several cities being analyzed show temporal trends, so the assumption of an independently distributed and identically distributed series of data with constant properties over time (stationary) needs to be modified to consider the effects of long-term climate change. In fact, there is increasing evidence that extreme series, whether thermal or hydroclimatic, are not stationary, due to natural climatic variability or anthropogenic climate change (Jain and Lall, 2001; Milly et al., 2008). Modeling of the non-stationarity within the
GEV distribution scheme requires improved models, in which model parameters are expressed as a function of time, and possibly with the incorporation of other covariates (El Adlouni et al., 2007; Leclerc and Ouarda, 2007; Panagoulia et al., 2013; Parey et al., 2018).

We incorporate the non-stationarity by allowing the location parameter $(\mu)$ of the GEV distribution to be time dependent (Renardt et al., 2013). Using the notation $(\mu, \sigma, \xi)$ to denote a GEV distribution with parameters $\mu, \sigma, \xi$, a suitable model for extreme temperatures in year $t, Z_{\mathrm{t}}$, could be as presented in Eq. (2) (Furió and Meneu, 2011):

$Z_{t} \approx G E V[\mu(t), \sigma, \xi]$

where $\mu(t)=\mu_{0}+\mu_{1}(t)$ for parameters $\mu_{0}$ and $\mu_{1}$. In this way, temporal variations in the observed process are modeled as a linear trend for the location parameter of the extreme value model, which in this case is the GEV distribution. The parameter $\mu_{0}$ corresponds to the value of $\mu$ when $t$ is the initial time, whereas the parameter $\mu_{1}$ corresponds to the annual rate of change in annual extreme temperatures.

\section{4 Parameter estimation}

Many techniques have been proposed for the estimation of parameters in extreme value models. The maximum likelihood method is a general and flexible estimation method for the unknown parameters $\mu$, $\sigma$, and $\xi$ within a family $F$. This technique estimates the parameters to give maximum probability to the observed values. In addition, the method allows for the inclusion of covariates such as time into the model (Katz et al., 2005). This approach is particularly attractive, due to its adaptability to complex constructions of models in techniques based on plausibility (Coles, 2001). It should be mentioned that this estimation technique has an inherent difficulty, in that the maximum likelihood estimators must be within certain limits, so that the conditions of regularity required by the asymptotic properties are valid. That is, if $\xi>-0.5$, the obtained parameter estimators are regular in the sense of having the usual asymptotic properties; when $-1<\xi<-0.5$, the estimators can generally be obtained, but do not have standard asymptotic properties; and when $\xi<-1$, the estimators are unlikely to be obtained (Smith, 2001). 
The maximum likelihood method was chosen in this study to estimate the parameters, mainly because: (a) the data sample for each climate station is sufficiently large (with the exception of Tuxtla Gutiérrez and Toluca, all of the other climate stations have series larger than 40 years), and accordingly it is comparable in performance to other methods; (b) it allows for the easy incorporation of covariate information (non-stationary distributions, which, as we will see, are frequently presented in this study), and (c) it is easier to obtain error limits than in most alternative methods. Eq. (1) assumes that the data are maximum or minimum annual blocks. The estimation of $\mu, \sigma$, and $\xi$ is performed using the maximum likelihood function for the independent maxima of annual blocks $z_{1}, \ldots, z_{\mathrm{n}}$ according to Eq. (3):

$L(\mu, \sigma, \xi)=\prod_{i=1}^{k} \frac{d G\left(z_{i} ; \mu, \sigma, \xi\right)}{d z_{i}}$

\subsection{Return levels}

When considering the extreme values of a random variable, the interest lies in determining the level of return of an extreme event, which is defined as a certain value $z_{\mathrm{p}}$. In that regard, $p$ is the probability that the $z$ value is exceeded in a year or, alternatively, the level that is expected to be exceeded on average once every $1 / p$ years ( $1 / p$ is often referred to as the return period). In the terminology of extreme values, $z_{\mathrm{p}}$ is the level of return associated with the return period $1 / p$ (Cooley et al., 2007), and basically refers to the average waiting time until the $z$ level is exceeded again.

The return level is obtained from the GEV distribution by the cumulative distribution function, which is equal to the desired probability/quantile ratio, 1- $p$. Estimates of the return levels for the distribution of maximum or minimum annual values can be obtained with Eq. (4), by obtaining estimators of their parameters by the maximum likelihood method:

$z_{p}=\left\{\begin{array}{c}\mu-\frac{\sigma}{\xi}\left[1-y_{p}^{-\xi}\right], \text { for } \xi \neq 0 \\ \mu-\sigma \log y_{p}, \text { for } \xi=0\end{array}\right.$

where $p=-\log (1-p)$. In addition, by the delta method (Eq. [5]):

$\operatorname{Var}\left(z_{p}\right) \cong \nabla z_{p}^{T} V \nabla z_{p}$ where $V$ is the variance-covariance matrix of $(\mu, \sigma$, $\xi)$, and with Eq. (6):

$$
\nabla z_{p}^{T}=\left[\frac{\partial z_{p}}{\partial \mu}, \frac{\partial z_{p}}{\partial \sigma}, \frac{\partial z_{p}}{\partial \xi}\right]
$$

The above is evaluated in $(\mu, \sigma, \xi)$. Caution should be exercised in interpreting inferences of return levels, especially for long periods of return; this is because the normal approximation to the distribution of the maximum likelihood estimator may be poor, and generally better approximations are obtained with the likelihood profile function. This methodology can be applied when it is required to make an inference regarding some combination of parameters. We can obtain confidence intervals for any $z_{\mathrm{p}}$ return level. This requires a reparameterization of the GEV model, so that $z_{\mathrm{p}}$ is one of the parameters of the model; the log-likelihood profile is obtained by maximization with respect to the remaining parameters in the usual way (Coles, 2001) and is obtained by means of Eq. (7):

$\mu=z_{p}+\frac{\sigma}{\xi}\left[1-\{-\log (1-\mathrm{p})\}^{-\xi}\right]$

In this way, the GEV model is expressed in terms of the parameters $\left(z_{\mathrm{p}}, \sigma, \xi\right)$. For the choice of the GEV model and to evaluate the strength of the evidence of more complex models (stationary or non-stationary), the criteria of the likelihood ratio test were applied, along with those of Akaike and Bayes.

\subsection{Likelihood ratio test}

By including more parameters in the model, the maximized likelihood function will necessarily increase (Coles, 2001), and this method confirms whether the improvement is statistically significant. The test compares two nested models, and thus one model, a base model, must be contained in another model with more parameters.

Formally, the likelihood ratio test (LRT) says that if you have two models, one called $\mathrm{M}_{0}$ which is the simplest model adjusted to the extreme data set, and another called $\mathrm{M}_{1}$ to which a covariate has been added to improve the behavior of the same extreme data, then a proof of the validity of the model $\mathrm{M}_{0}$ relative to the model $\mathrm{M}_{1}$ at the level of significance $\alpha$ is to reject $M_{0}$ in favor of $M_{1}$ if: 
$D=2\left\{l_{1}\left(M_{1}\right)-l_{0}\left(M_{0}\right)\right\}>c_{\alpha}$

where $c_{\alpha}$ is the quantile of the distribution. In Eq. (8), $l_{1}\left(\mathrm{M}_{1}\right)$ is the maximized likelihood logarithm for the $\mathrm{M}_{1}$ model, and $l_{0}\left(\mathrm{M}_{0}\right)$ the maximized likelihood logarithm for the $\mathrm{M}_{0}$ model.

\subsection{Akaike and Bayes information criteria}

Alternatives to the LRT for comparing the relative quality of a statistical model include the Akaike information criterion (AIC) and the Bayes information criterion (BIC), which were also used in the selection of the best model for adjustment. None of these criteria require a nested model as in the LRT. The AIC is defined according to Eq. (9):

$\operatorname{AIC}(\mathrm{p})=2 n_{\mathrm{p}}-2 l$

where $n_{\mathrm{p}}$ is the number of parameters in a model of order $\mathrm{p}$, and $l$ is its maximized value of log-likelihood (Thiombiano et al., 2017). The best model is the one with the smallest AIC value (Katz, 2013; Mondal and Mujumdar, 2015). Similarly, for the adjustment of a model of order $p$ to data with a sample size of $n$, the BIC is determined with Eq. (10):

$\mathrm{BIC}(\mathrm{p})=n_{\mathrm{p}}(\ln n \mathrm{n})-2 l$

Both the AIC and BIC attempt to counteract the problem of over adjusting a model by adding more parameters, through the incorporation of a penalty based on the number of parameters (Panagoulia et al., 2013). The BIC is more parsimonious than the AIC. Among the candidate models, the model with the lowest AIC/BIC ratio is preferred.

Given that the database for each city appears to be sufficiently large ( $\mathrm{n}>30$ years), the maximum likelihood method is confirmed for the estimation of the three parameters of the GEV distribution. This is basically because the method easily incorporates covariable information into the estimates of the parameters. Besides, it has a series of attractive properties and it seems to be more suitable for situations in which climate change within the sample analyzed cannot be ignored (Kharin and Zwiers, 2005).

The modeling was supported by the free software $\mathrm{R}$ and the in2extRemes package that is designed to be used in the analysis of extreme weather and climate events (Gilleland and Katz, 2005, 2013).

\section{Results and discussion}

In this section we present and analyze the results of the parametric approach based on the GEV distribution for modeling the maximum annual value of the TXX and TNN for each of the selected urban areas in Mexico. The data series are analyzed in each climatological station, the use of stationary and non-stationary models is evaluated, and a statistical evaluation of the changes in TXX and TNN is presented.

We modeled the data series through the GEV distribution of three parameters, using stationary and non-stationary models for periods that varied from 83 years (Veracruz) to 31 years (Tuxtla Gutiérrez); the other cities had intermediate periods (Table I). The inclusion of non-stationarity is plausible for our modeling approach, as can be visualized for many locations. As an example, time series of TXX (Figs. 4, 6, 8, and 10) and TNN (Figs. 5, 7, 9, and 11) are shown for four of the 12 urban areas (Tijuana, Guadalajara, Toluca, and Puebla), with a trend line using Sen's slope estimator. The graphs for several cities show a clear trend in the maximum and minimum annual data. The graphical analysis and results of the Mann-Kendall trend test justify the use of non-stationary GEV models over time as a covariate. The trends shown are statistically significant with a p-value $<0.05$, except for the TXX of Toluca, whose trend is significant with a p-value $<0.1$, and the TXX of Tijuana, whose trend is not significant.

The time series of TXX and TNN were used to estimate the parameters in the distribution of GEV with and without trends, as well as the periods of

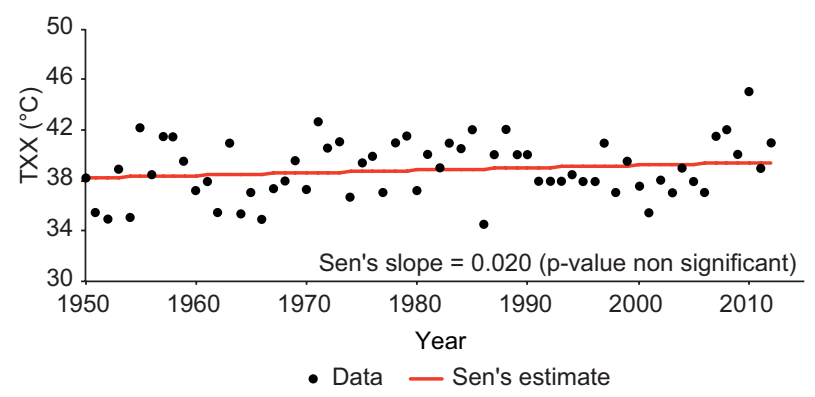

Fig. 4. Trend of extreme maximum temperature (TXX) in Tijuana from 1950 to 2012. 


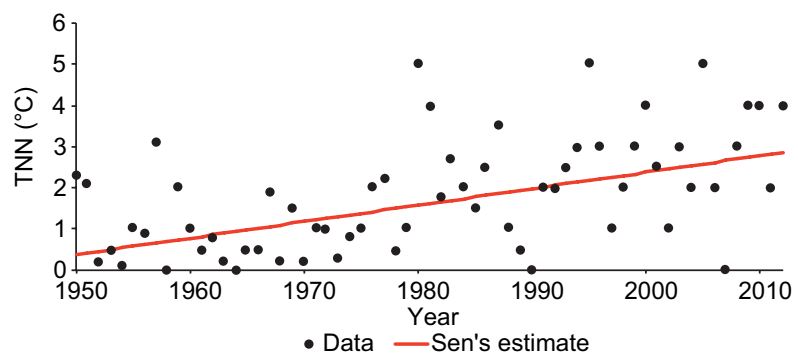

Fig. 5. Trend of extreme minimum temperature (TNN) in Tijuana from 1950 to 2012.

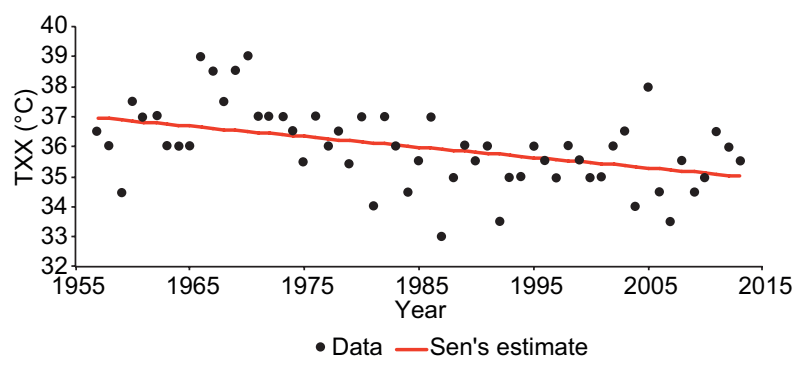

Fig. 6. Trend of extreme maximum temperature (TXX) in Guadalajara from 1957 to 2013.

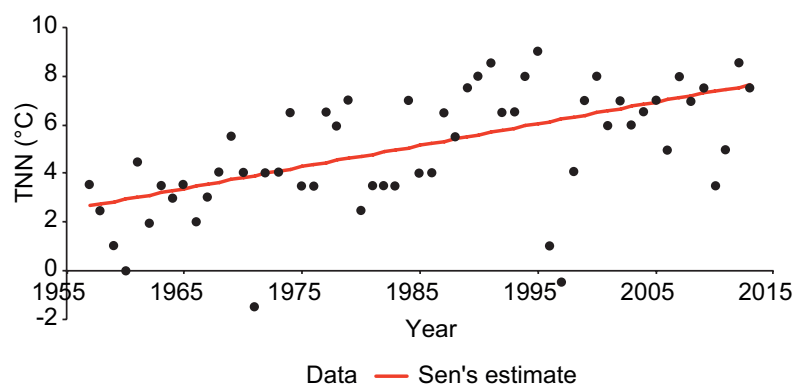

Fig. 7. Trend of extreme minimum temperature (TNN) in Guadalajara from 1957 to 2013.

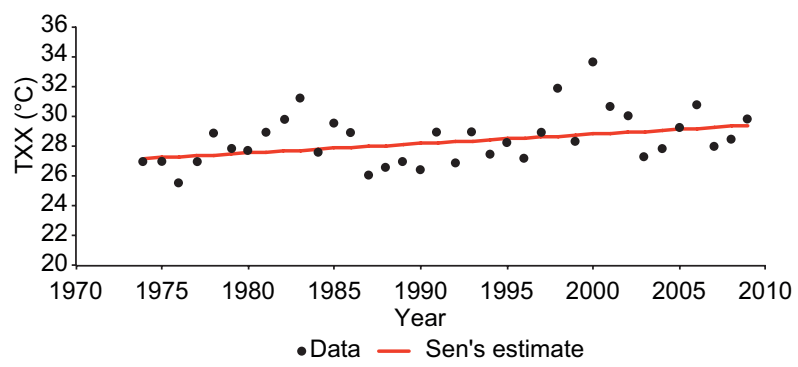

Fig. 8. Trend of extreme maximum temperature (TXX) in Toluca from 1974 to 2009.

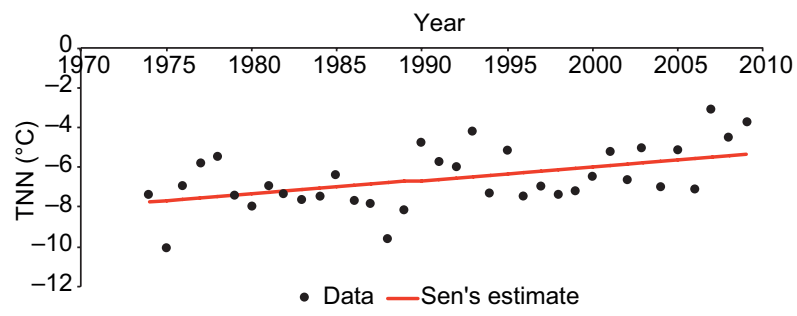

Fig. 9. Trend of extreme minimum temperature (TNN) in Toluca from 1974 to 2009 .

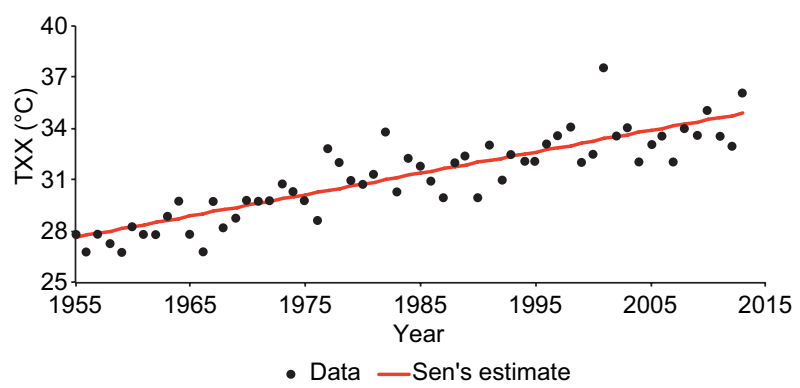

Fig. 10. Trend of extreme maximum temperature (TXX) in Puebla from 1955 to 2013.

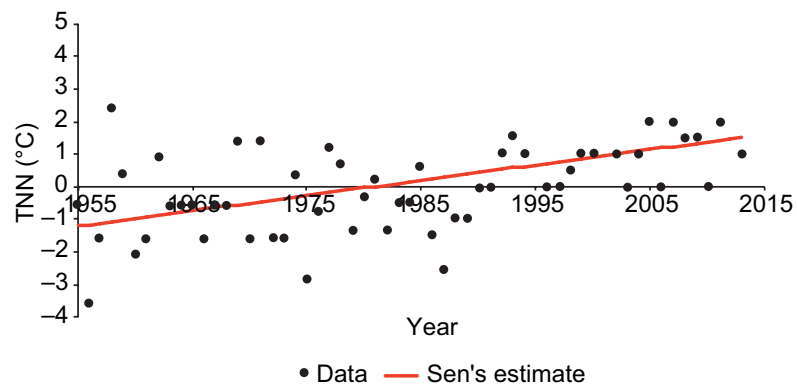

Fig. 11. Trend of extreme minimum temperature (TNN) in Puebla from 1955 to 2013.

return. The models were adjusted to the maximum annual temperature and minimum annual temperature of each of the 16 climate stations using the maximum likelihood (ML) method.

An attempt was made to improve the modeling approach by allowing the location parameter $(\mu)$ to depend on time. As mentioned, three model selection criteria (AIC, BIC, and LRT) were used to select the best model from a collection of nested models. The best adjustment models for TXX and TNN through the GEV distributions, as selected by the criteria separately listed for each urban area, are summarized in Table II. 


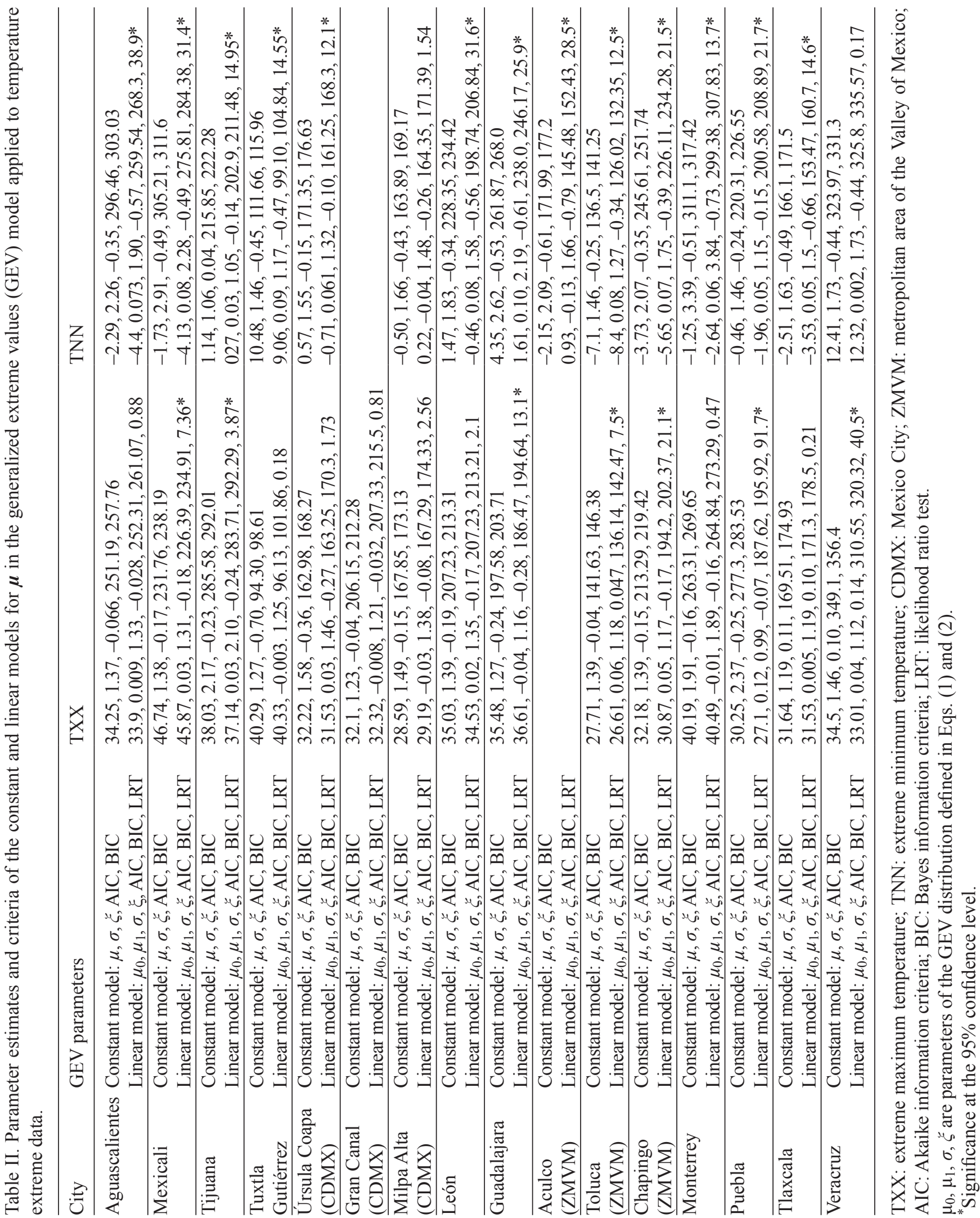


In total, 58 models were generated. Table II shows the resulting estimators and the criteria for selecting the best model to be used in the estimation of return periods. According to this table, for the temporal trend of TXX, significant at a 95\% confidence level, it can be seen that: (a) $44 \%$ of locations (seven urban areas) show a significant trend, (b) 50\% of locations (eight urban areas) have no significant trend, and (c) $6 \%$ of locations (one urban area) show no trend. For the temporal trend of TNN, also significant at the $95 \%$ confidence level, it was found that: (a) $82 \%$ of locations (13 urban areas) show a significant trend, (b) $12 \%$ of locations (two urban areas) show no significant trend, and (c) $6 \%$ of locations (one urban area) show no trend.

According to the shape parameter $(\xi)$, and by performing a detailed analysis, it was found that for the case of TXX, $63 \%$ of the climatic stations were adjusted to the Weibull distribution $(\xi<0), 25 \%$ were adjusted to the Gumbel distribution, $6 \%$ were adjusted to the Fréchet distribution, and $6 \%$ did not fit any of the three distributions. In the case of TNN, $94 \%$ of the analyzed climatic stations were adjusted to the Weibull distribution, and only $6 \%$ did not adjust to any of the distributions.

In the case of TXX, which exhibits a significant temporal trend, it was found that $72 \%$ was adjusted to the Weibull distribution, $14 \%$ to the Gumbel distribution, and $14 \%$ to the Fréchet distribution. For TNN, it was found that those that show a significant temporal trend $(82 \%)$ and those that are stationary $(12 \%)$ conformed to the Weibull distribution.

Overall, for both extreme temperatures TXX and TNN, it was found that the $57 \%$ following the Weibull distribution are statistically significant to the temporal trend at the $95 \%$ confidence level. One of the properties of this distribution, which may even be controversial because of the trend found, is that both extreme temperatures have an upper limit that cannot be exceeded.

Figures 12 and 13 describe the temporal trend pattern of decadal trends for the location parameter $(\mu)$ of the maximum and minimum temperatures according to non-stationary GEV models (Table II). About the TXX (Fig. 12), the most significant positive trend occurred in the center and east regions (Toluca, Chapingo, Puebla and Veracruz), whereas the lowest trends occurred in the northwest regions (Tijuana and Mexicali).

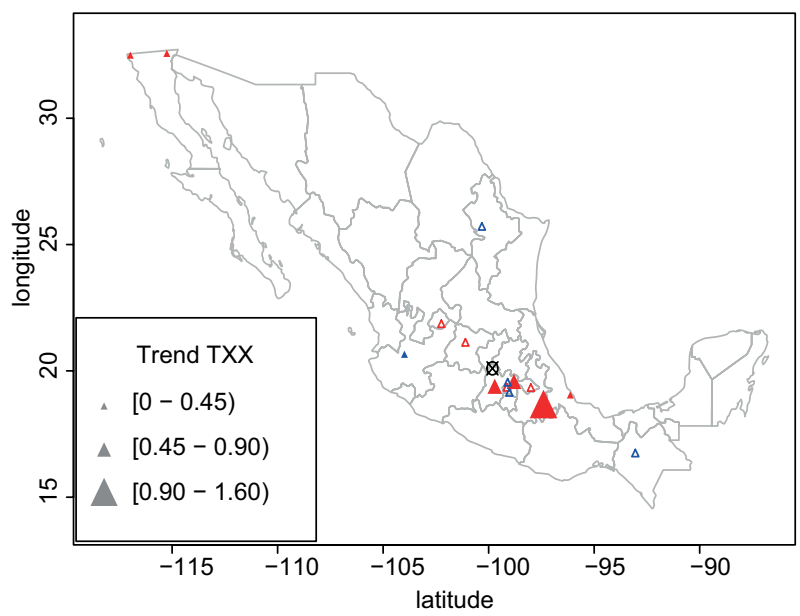

Fig. 12. Spatial patterns of trends of the location parameter $(\mu)$ for the maximum temperature. Red (blue) triangles mean positive (negative) values. Full triangles mean significant trends at the $5 \%$ level. The symbol $\otimes$ indicates without change.

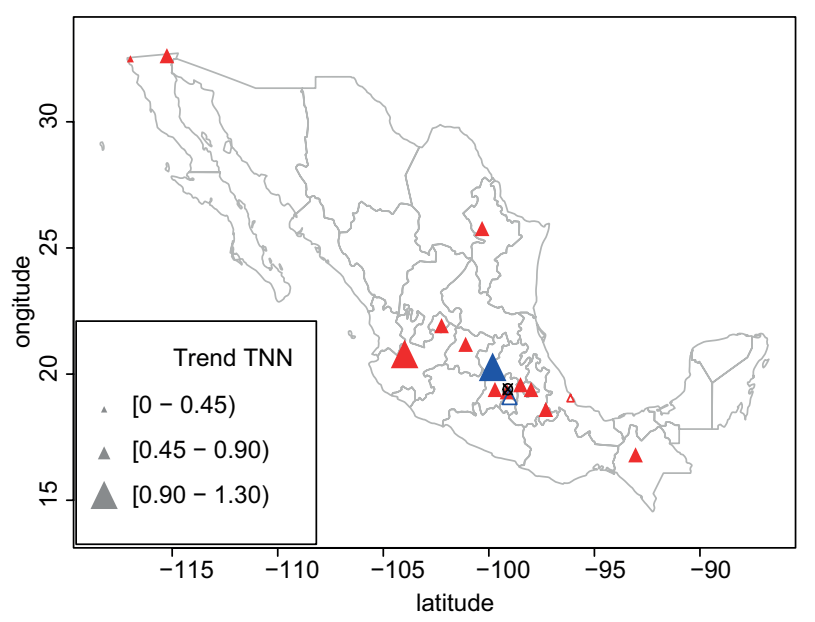

Fig. 13. Spatial patterns of trends of the location parameter $(\mu)$ for the minimum temperature. Red (blue) triangles mean positive (negative) values. Full triangles mean significant trends at the $5 \%$ level.

Respect to the TNN (Fig. 13), the most significant positive trends were most relevant in different geographical areas of the country, i.e., higher in the west center (Guadalajara and León), southeast (Tuxtla Gutiérrez), some urban areas located in the central part (Úrsula Coapa, Toluca, Chapingo, Tlaxcala and 
Puebla), and in the northeast and northwest (Monterrey and Mexicali), whereas the lowest positive trend occurred in the urban area of Tijuana (with a value of 0.30). The most significant negative trend occurred in an urban area.

Once the best models were selected, the return levels of the extreme, maximum, and minimum temperatures were estimated. Tables III and IV present the estimators and confidence intervals for return levels to $10,20,50$, and 100 years, for both stationary and non-stationary models. The stationary return levels for TXX in Table III, indicate that the values increase for increasingly larger periods $(10,20,50$, and 100 years), except for the urban area of Tuxtla Gutiérrez. In addition, the confidence intervals were increasingly wider as the periods of return increased. In Aguascalientes the TXX can be expected to progressively exceed $37.1^{\circ} \mathrm{C}$ on average every 10 years, $37.9^{\circ} \mathrm{C}$ on average every 20 years, $38.9^{\circ} \mathrm{C}$ on average every 50 years, and $39.7^{\circ} \mathrm{C}$ on average every 100 years. The $95 \%$ confidence intervals for these return periods, in ${ }^{\circ} \mathrm{C}$, were $36.4-37.8,37.0-38.9,37.5-40.4$, and $37.8-41.5$, respectively.
Among the locations considered in that block, and in the context of the stationary return levels, Monterrey (in the northeast of the country) was associated with the highest return levels, and Milpa Alta (in the metropolitan area of the Valley of Mexico in the center of the country) had the lowest return levels. Based on the $95 \%$ confidence interval and according to Table III, we can expect that the largest TXX event recorded for Milpa Alta could reappear for the next 10 years. Moreover, there is a high probability that the annual TXX will exceed the maximum historical value in the next 50 years, except in the sites Gran Canal and Monterrey.

The estimated return levels assume stationarity, meaning that the level of return for a return period is the same for the successive years. This implies that the statistical properties of the parameters $\mu, \sigma$, and $\xi$ are constant.

In a non-stationary case, the parameters of the GEV distribution vary over time, and the return levels of extreme temperatures will also follow that temporal trend. Under a changing climate, the return value can be interpreted as an extreme quantile of a

Table III. Stationary and non-stationary return levels for extreme maximum temperature and its $95 \%$ confidence levels (in parentheses).

\begin{tabular}{lcccc}
\hline Urban zone & $\begin{array}{c}\text { Return levels } \\
(10 \text { years })\end{array}$ & $\begin{array}{c}\text { Return levels } \\
(20 \text { years })\end{array}$ & $\begin{array}{c}\text { Return levels } \\
(50 \text { years })\end{array}$ & $\begin{array}{c}\text { Return levels } \\
(100 \text { years })\end{array}$ \\
\hline \multicolumn{5}{c}{ Stationary return levels $\left({ }^{\circ} \mathrm{C}\right)$} \\
\hline Aguascalientes & $37.1(36.4-37.8)$ & $37.9(37.0-38.9)$ & $38.9(37.5-40.4)$ & $39.7(37.8-41.5)$ \\
Tuxtla Gutiérrez & $41.7(41.5-42.0)$ & $41.9(41.7-42.0)$ & $42.0(41.8-42.2)$ & $42.0(41.8-42.2)$ \\
Úrsula Coapa & $34.7(34.2-35.2)$ & $35.1(34.6-35.6)$ & $35.5(35.0-36.1)$ & $35.8(35.1-36.4)$ \\
Gran Canal & $34.7(34.0-35.4)$ & $35.5(34.6-36.5)$ & $36.5(35.1-37.9)$ & $37.2(35.4-39.1)$ \\
Milpa Alta & $31.4(30.7-32.2)$ & $32.2(31.2-33.1)$ & $33.0(31.8-34.2)$ & $33.6(32.0-35.1)$ \\
León & $37.6(37.0-38.1)$ & $38.2(37.5-38.9)$ & $38.9(37.9-39.8)$ & $39.3(38.8-40.4)$ \\
Monterrey & $43.8(43.0-44.6)$ & $44.7(43.8-45.6)$ & $45.7(44.6-46.9)$ & $46.4(45.0-47.7)$ \\
Tlaxcala & $34.7(33.6-35.8)$ & $35.8(34.1-37.6)$ & $37.5(34.4-40.5)$ & $38.8(34.5-43.2)$ \\
\hline \multicolumn{5}{c}{ Non-stationary return levels $\left({ }^{\circ} \mathrm{C}\right)$} \\
\\
\hline Mexicali & $48.5(48.0-49.1)$ & $49.4(48.8-50.1)$ & $50.9(50.1-51.7)$ & $52.7(51.7-53.7)$ \\
Tijuana & $41.1(40.3-41.8)$ & $42.2(41.3-43.0)$ & $43.9(42.8-45.0)$ & $45.9(44.5-47.2)$ \\
Guadalajara & $38.2(37.8-38.7)$ & $38.3(37.7-38.8)$ & $37.6(36.9-38.3)$ & $36.1(35.2-36.9)$ \\
Toluca & $30.0(28.9-31.0)$ & $31.5(30.1-32.9)$ & $34.6(32.4-36.8)$ & $38.6(35.7-41.5)$ \\
Chapingo & $33.5(32.9-34.1)$ & $34.5(33.8-35.3)$ & $36.6(35.6-37.6)$ & $39.5(38.2-40.7)$ \\
Puebla & $30.2(29.4-31.0)$ & $32.0(31.0-32.9)$ & $36.3(35.1-37.5)$ & $42.8(41.4-44.2)$ \\
Veracruz & $36.3(35.3-37.3)$ & $37.9(36.2-39.5)$ & $40.7(37.9-43.5)$ & $44.0(40.0-48.1)$ \\
\hline
\end{tabular}


Table IV. Stationary and non-stationary return levels for extreme minimum temperature and its $95 \%$ confidence levels (in parentheses).

\begin{tabular}{lcccc}
\hline Urban zone & $\begin{array}{c}\text { Return levels } \\
(10 \text { years })\end{array}$ & $\begin{array}{c}\text { Return levels } \\
(20 \text { years })\end{array}$ & $\begin{array}{c}\text { Return levels } \\
(50 \text { years })\end{array}$ & $\begin{array}{c}\text { Return levels } \\
(100 \text { years })\end{array}$ \\
\hline \multicolumn{5}{c}{ Stationary return levels $\left({ }^{\circ} \mathrm{C}\right)$} \\
\hline Milpa Alta & $1.9(1.4-2.3)$ & $2.3(1.8-2.7)$ & $2.6(2.2-3.1)$ & $2.8(2.3-3.3)$ \\
Veracruz & $14.9(14.6-15.2)$ & $15.3(15.0-15.6)$ & $15.6(15.3-16.0)$ & $15.8(15.5-16.2)$ \\
\hline \multicolumn{5}{c}{ Non-stationary return levels $\left({ }^{\circ} \mathrm{C}\right)$} \\
\hline Aguascalientes & $-1.3[-1.9-(-0.7)]$ & $-0.3[-1.0-(0.4)]$ & $2.1(1.3-3.0)$ & $5.9(4.9-7.0)$ \\
Mexicali & $-0.3[-0.9-(0.3)]$ & $1.0(0.4-1.6)$ & $3.8(3.1-4.5)$ & $8.0(7.1-8.8)$ \\
Tijuana & $2.6(1.8-3.4)$ & $3.4(2.2-4.7)$ & $5.0(2.8-7.3)$ & $7.1(3.9-10.3)$ \\
Tuxtla Gutiérrez & $11.5(11.1-12.0)$ & $12.7(12.3-13.2)$ & $15.8(15.2-16.3)$ & $20.6(19.9-21.2)$ \\
Úrsula Coapa & $2.5(1.7-3.3)$ & $3.8(2.9-4.8)$ & $6.5(5.3-7.8)$ & $10.2(8.6-11.8)$ \\
León & $2.3(1.7-2.8)$ & $3.3(2.7-3.8)$ & $5.8(5.2-6.5)$ & $9.8(9.0-10.5)$ \\
Guadalajara & $5.2(4.7-5.7)$ & $6.5(6.1-7.0)$ & $9.8(9.3-10.2)$ & $14.9(14.4-15.4)$ \\
Aculco & $2.6(2.2-2.9)$ & $2.6(2.3-2.9)$ & $2.3(1.9-2.7)$ & $1.7(1.3-2.1)$ \\
Toluca & $-5.7[-6.4-(-5.0)]$ & $-4.6[-5.3-(-3.8)]$ & $-1.9[-2.9-(-0.8)]$ & $2.2(1.0-3.4)$ \\
Chapingo & $-2.4[-3.0-(-1.8)]$ & $-1.2[-1.8-(-0.6)]$ & $1.3(0.6-2.0)$ & $5.1(4.3-5.9)$ \\
Monterrey & $2.1(1.5-2.8)$ & $3.1(2.5-3.7)$ & $5.1(4.5-5.6)$ & $8.0(7.5-8.6)$ \\
Puebla & $0.7(0.2-1.2)$ & $1.8(1.2-2.4)$ & $3.9(3.2-4.7)$ & $6.9(6.0-7.8)$ \\
Tlaxcala & $-1.3[-1.7-(-1.0)]$ & $-0.6[-1.0-(-0.3)]$ & $1.0(0.6-1.3)$ & $3.5(3.1-3.9)$ \\
\hline
\end{tabular}

temperature distribution that varies over time (for example, a return value of 20 years can be interpreted as a value that has a $5 \%$ probability to be exceeded in a particular year).

It is now possible to estimate return levels for any year, which are also presented in Table III. For example, note that the average return levels $\left(\right.$ in $\left.^{\circ} \mathrm{C}\right)$ for Mexicali for 10, 20, 50, and 100 years, are 48.5, 49.4, 50.9 and 52.7, respectively. The confidence intervals at $95 \%$ (in ${ }^{\circ} \mathrm{C}$ ) are 48.0-49.1, 48.8-50.1, 50.1-51.7, and 51.7-53.7, respectively. The differences in return levels between stations is remarkable, both in the stationary GEV models and in the non-stationary models. Mexicali, in the northwest of Mexico, is associated with the highest return levels, whereas Milpa Alta, a metropolitan area in Mexico City, has the lowest return levels.

With respect to TNN, Table IV shows that only stations Milpa Alta and Veracruz have stationary return levels, and that the values increase slightly for increasingly large return periods $(10,20,50$, and 100 years). In addition, the confidence intervals remain nearly constant as the periods of return increase. For example, Milpa Alta could expect the TNN to exceed $1.9^{\circ} \mathrm{C}$ on average every 10 years, $2.3^{\circ} \mathrm{C}$ on average every 20 years, $2.6^{\circ} \mathrm{C}$ on average every 50 years, and $2.8^{\circ} \mathrm{C}$ on average every 100 years. The confidence intervals, at $95 \%$ (in ${ }^{\circ} \mathrm{C}$ ) are 1.4-2.3, 1.8-2.7, 2.2-3.1, and 2.3-3.3, respectively.

As already mentioned, the estimated return levels assume stationarity, meaning that the level of return for a return period is the same for successive years. This also implies that the statistical properties, as mentioned for TXX, keep the parameters $\mu, \sigma, \mathrm{y}$, and $\xi$ constant.

In a non-stationary case (as with TXX), the parameters vary in time and the return levels of extreme temperatures will follow a similar temporal trend. It is possible to estimate return levels for any year of interest in a time period. The return levels for the non-stationary TNN series are presented in Table IV. Note that the average return levels of 10 , 20, 50, and 100 years $\left(\mathrm{in}^{\circ} \mathrm{C}\right.$ ) for Aguascalientes are $-1.3,-0.3,2.1$, and 5.9 , respectively, whereas their confidence intervals, at $95 \%$ and in ${ }^{\circ} \mathrm{C}$, progress from -1.9 to $-0.7,-1.0$ to $0.4,1.3$ to 3.0 , and 4.9 to 7.0 , respectively.

In the case of a non-stationary series, for both TXX and TNN, a positive trend of the location parameter $\left(\mu_{1}\right)$ will be reflected in the positive trend of 
the return levels (Chen and Chu, 2014). This means that with greater magnitudes of the trend return levels will increase considerably, and threshold values of return levels will contain greater variation over time. As examples of estimators of return levels, the time series of return levels for TXX for the city of Puebla (Fig. 14) and for TNN for the city of Guadalajara (Fig. 15) are plotted, according to the GEV adjustment non-stationary model. The difference in the return level for 2 years for the city of Puebla from the beginning of the period (1955) to the end (2013) is approximately $5{ }^{\circ} \mathrm{C}$, whereas the difference in the return level of 2 years for the city of Guadalajara from the beginning of the period (1957) to the end (2013) is approximately $3{ }^{\circ} \mathrm{C}$.

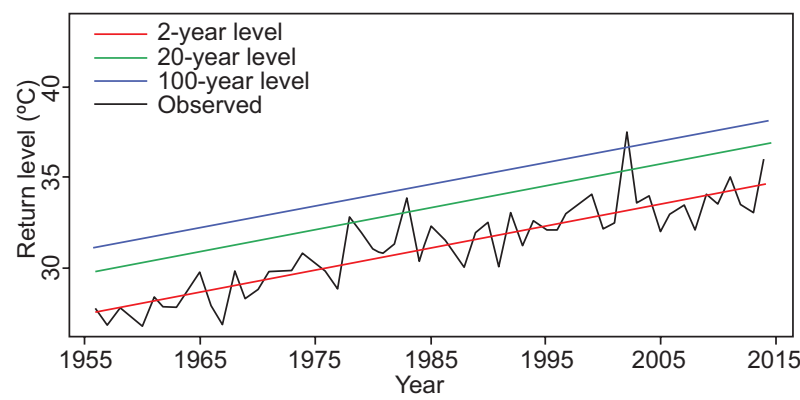

Fig. 14. Time series of extreme maximum temperature (TXX) return levels in Puebla in accordance with the non-stationary generalized extreme value (GEV) model. The red, green, and blue lines represent the return levels of 2, 20, and 100 years, respectively. The black line represents observed values.

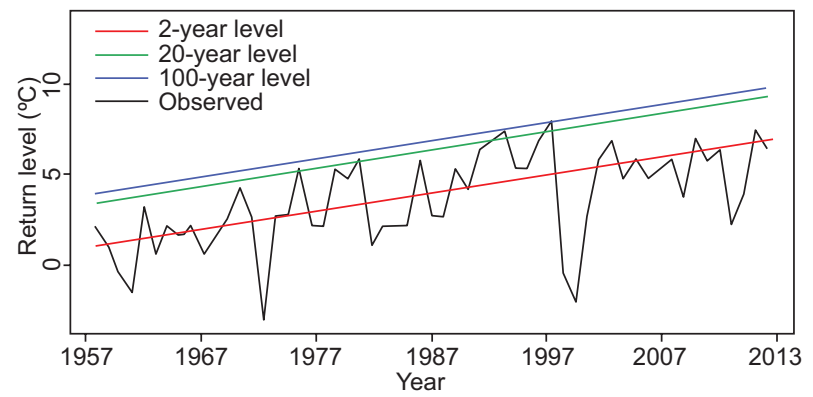

Fig. 15. Time series of extreme minimum temperature (TNN) return levels in Guadalajara in accordance with the non-stationary GEV model. The red, green, and blue lines represent the return levels of 2, 20, and 100 years, respectively. The black line represents observed values.
The application of the stationary and non-stationary GEV distributions has allowed this study to model the behavior of extreme temperatures in some cities of Mexico. Due to the lack of reliable data, only 16 climate stations were used, focusing on 12 urban areas. The latitudinal dispersion of these climatic stations ranged from $16^{\circ} 45^{\prime}$ (Tuxtla Gutiérrez) to $32^{\circ} 39^{\prime}$ (Mexicali), and with altitudes above sea level varying from $4 \mathrm{~m}$ (Mexicali) to $2726 \mathrm{~m}$ (Toluca). This resulted in several types of climates according to the geographical location (García-Cueto et al. 2018), making the analysis by chosen city even more interesting. This is particularly true for those cities that show significant trends and periods of return that could put the adaptation of people and the urban ecosystem at risk, particularly the fauna and flora. We found that the TXX is increasing in Mexicali, Tijuana, Toluca, Chapingo, Puebla and Veracruz, and no significant changes were detected in the other 10 urban zones. A larger number of climatological stations indicate increasing TNN compared to TXX, namely Aguascalientes, Mexicali, Tijuana, Tuxtla Gutiérrez, Úrsula Coapa, León, Guadalajara, Aculco, Toluca, Chapingo, Monterrey, Puebla and Tlaxcala. Non significant increases were detected in only two stations, i.e., Milpa Alta and Veracruz.

A comparison of the obtained results with those from studies using the ETCDDI indices shows similarities and some differences. For example, García-Cueto et al. (2018) used the same database herein and found a statistically significant increasing trend in the TX90 (warm days) and TN90 (warm nights) indices for Aguascalientes, whereas for Milpa Alta, both indices (TX90 and TN90) decreased significantly. The difference is between the TXX (stationary in this study) and TX90 (increasing trend) for Aguascalientes; in the case of Milpa Alta, there are coincidences in both indices (TXX with TX90 and TNN with TN90) that show decreasing trends.

At the country level, according to Gosling et al. (2011), Mexico has experienced a generalized warming since 1960. The frequency of cold days has decreased, and the frequency of warm nights has increased. There has also been a general increase in average winter temperatures in the country as a result of human influences on climate. Thus, during the winter season, the occurrences of warm temperatures are more frequent, and those of cold temperatures are 
less frequent. For the A1B emissions scenario, the projected temperature increases of the Coupled Model Intercomparison Project Phase 3 (CMIP3) over Mexico are approximately $4{ }^{\circ} \mathrm{C}$ near the US border, with increases in the rest of the country between 2.5 and $3.5^{\circ} \mathrm{C}$. This implies that the influence of GHGs will have an additive effect on the potential warming caused by urbanization. This can become a major problem affecting city dwellers both positively and negatively, depending on their latitudinal location.

Significant trends in extreme maximum and minimum temperatures found in many parts of the world (Heim Jr., 2015; Easterling et al., 2016; Houngninou et al., 2017) reinforce the results obtained here. In the US, extremely hot maximum and minimum temperatures have shown increasing trends between the 20th and 21 st centuries and during the last four decades (1971-2013), whereas the presence of extremely low and minimum temperatures has decreased during these periods (Hartmann et al., 2013).

The application of a theory of extreme events to the TXX and TNN in 16 climatological stations located in 12 urban areas of Mexico, in time series with different periods, showed general trends in urban warming, especially at night. However, values varied from city to city. A less clear detection signal was the diurnal heating. Although the causes for this behavior of heterogeneous trends for TXX and TNN may be of purely local origin and caused by the dynamics of urbanization (land use change, anthropogenic activities), it cannot be ruled that they could be caused by some other climatic phenomena of a greater scale. For example, Mexico could be exposed to blocking patterns, or modes of climate variability, such as the El Niño Southern Oscillation, Pacific Decadal Oscillation, North Atlantic Oscillation, or the Madden-Julian Oscillation, among others. These could be causal factors that contribute to thermal trends since in other regions of the world they have significantly influenced the behavior of extreme temperatures (Arblaster and Alexander, 2012; Parker et al., 2014; Burgess and Klingaman, 2015; Matsueda and Takaya, 2015). All these factors are considered important for possible attribution but are not the object of this study.

It is well known that cities will remain the most vulnerable geographic spaces, especially in developing countries such as Mexico, as they often concentrate large populations without adequate infrastructure. Thus, knowledge of regions where the climate is unstable (changing), and the knowledge that extreme climate events are not controllable, but have showed signals of an increasing trend, will serve to generate some potential urban adaptation strategies for facing current and future extreme temperatures. For example, such temperatures can be addressed by redesigning the urban space (making it safe, ecological and acceptable) to reduce vulnerability and strengthen urban water security. It should be noted that each city is a case of analysis, and that an adequate scheme of sustainable urban planning can only be accomplished through the participation of governmental authorities, productive sectors, academics, and local actors.

\section{Conclusions}

This study modeled the TXX and TNN recorded in 16 climatological stations corresponding to 12 cities in Mexico, for periods that varied according to the series of available data. The longest record corresponded to Veracruz with 85 years (19302014), and the shortest to Tuxtla Gutiérrez with 31 years (1980-2010). Through the application of the non-parametric Mann-Kendall test and the Sen method, a trend towards urban warming was detected, but no homogeneous behavior in all cities analyzed was found. An important observation was the significant prevalence of non-stationary series with the TXX in half of the cities analyzed; only Guadalajara, located in the center-west of the country, presented a significant negative trend, perhaps due the effect of "diming" by increases in aerosol pollution (Fonseca-Hernández et al., 2018). Therefore, the annual trends in daytime warming, represented by TXX, are not necessarily identical in all selected urban areas of Mexico. In the case of the TNN, which is related to night warming, the behavior was more uniform. Specifically, $90 \%$ of the cities are non-stationary with a significant positive trend, and only two areas presented a stationary series: one urban area located to the east of the metropolitan area of the Valley of Mexico (Milpa Alta), and another on the coast of the Gulf of Mexico (Veracruz). With the adjustment of the non-stationary GEV distribution to the data set and by incorporating the trend of the location parameter, the trends of the return levels of 10, 20, 50, and 
100 years were estimated, while keeping the shape and scale parameters constant.

The results are very similar to those from non-parametric trend detection methods, both for TXX and TNN. This confirms the non-stationary behavior of half of the stations for TXX, and $90 \%$ of the stations for TNN. Return periods of the thermal extremes estimated in a changing climate for many of the cities analyzed in this study vary significantly, and the regularity with which extreme temperatures are occurring is becoming more frequent. Thus, statistical modeling should consider this behavior, due to its importance for risk assessments for human health, flora and fauna, and urban infrastructure. The proposed non-stationary GEV model has provided new and important information concerning changes in extreme temperatures, and by estimating return periods, it has provided their probability of recurrence. Some main modes of climate variability as causal mechanisms of attribution of extreme temperatures have not been studied, making it a pending task.

\section{Acknowledgments}

The authors thank the United Nations Development Program and the National Institute of Ecology and Climate Change of Mexico for supporting this research. We would also like to thank the National Meteorological Service of Mexico for providing daily climate information for this study.

\section{References}

Alexander LV, Zhang X, Peterson TC, Caesar J, Gleason B, Klein Tank AMG, Haylock M, Collins D, Trewin B, Rahimzadeh F, Tagipour A, Rupa Kumar K, Revadekar J, Griffiths G, Vincent L, Stephenson DB, Burn J, Aguilar E, Brunet M, Taylor M, New M, Zhai P, Rusticucci M, Vázquez-Aguirre JL. 2006. Global observed changes in daily climate extremes of temperature and precipitation. Journal of Geophysical Resources 111: D05109. https://doi.org/10.1029/2005JD006290

Almazroui M, Islam MN, Dambul R, Jones PD. 2014. Trends of temperature extremes in Saudi Arabia. International Journal of Climatology 34: 808-826. https:// doi.org/10.1002/joc.3722

Arblaster JM, Alexander LV. 2012. The impact of the El Nino-Southern Oscillation on maximum temperature extremes. Geophysical Resource Letters 39: L20702. https://doi.org/10.1029/2012GL053409

Beniston M, Stephenson DB, Christensen OB, Ferro AT, Frei Ch, Goyette S, Halsnaes K, Holt T, Jylhä K, Koffi B, Palutikof J, Schöll R, Semmler T, Woth K. 2007. Future extreme events in European climate: An exploration of regional climate model projections. Climatic Change 81: 71-95. https://doi.org/10.1007/ s10584-006-9226-z

Boucefiane A, Meddi M. 2019. Regional growth curves and extreme precipitation events estimation in the steppe area of northwestern Algeria. Atmósfera 32: 287-303. https://doi.org/10.20937/ATM.2019.32.04.03

Brown SJ, Caesar J, Ferro CAT. 2008. Global changes in extreme daily temperature since 1950 . Journal of Geophysical Research: Atmosphere 113: D05115. https://doi.org/10.1029/2006JD008091

Burgess ML, Klingaman NP. 2015. Atmospheric circulation patterns associated with extreme cold winters in the UK. Weather 70: 211-217. https://doi.org/10.1002/ wea. 2476

Burgman M, Franklin J, Keith RK, Hosack RG, Peters WG, Sisson AS. 2012. Modeling extreme risks in ecology. Risk Analysis 32: 1956-1966. https://doi. org/10.1111/j.1539-6924.2012.01871.x

Burn DH, Hag Elnur AM. 2002. Detection of hydrological trends and variability. Journal of Hydrology 255: 107122. https://doi.org/10.1016/S0022-1694(01)00514-5 Caesar J, Alexander LV, Trewin B, Tse-ring K, Sorany L, Vuniyayawa V, Keosavang N, Shimana A, Htay MM, Karmacharya J, Jayasinghearachchi DA, Sakkamart J, Soares E, Hung LT, Thuong LT, Hue CT, Dung NTT, Hung PV, Cuong HD, Cuong NM, Sirabaha S. 2011. Changes in temperature and precipitation extremes over the Indo-Pacific region from 1971 to 2005 . International Journal of Climatology 31: 791-801. https:// doi.org/10.1002/joc. 2118

Caloiero T. 2017. Trend of monthly temperature and daily extreme temperature during 1951-2012 in New Zealand. Theoretical Applied of Climatology 129: 111-127. https://doi.org/ 10.1007/s00704-016-1764-3

Cavazos T, Rivas D. 2004. Variability of extreme precipitation events in Tijuana, Mexico. Climate Research 25: 229-243. https://doi.org/10.3354/cr025229

Cavazos T, Salinas JA, Martínez B, Colorado G, de Grau P, Prieto González R, Bravo ME. 2013. Actualización de escenarios de cambio climático para México como parte de los productos de la quinta comunicación 
nacional. Informe final. CICESE-IMTA-CCA UNAM, 150 pp. Available at: https://www.researchgate.net/ publication/321274898 (last accessed on June 1, 2019).

Chen YR, Chu P-S. 2014. Trends in precipitation extremes and return levels in the Hawaiian Islands under a changing climate. International Journal of Climatology 34: 3913-3925. https://doi.org/10.1002/joc.3950

Chen W, Chen C, Li L, Xing L, Huang G, Wu C. 2015. Spatio-temporal analysis of extreme hourly precipitation patterns in Hainan Island, South China. Water 7: 2239-2253. https://doi.org/10.3390/w7052239

CIDOC-SHF. 2011. Current housing situation in Mexico 2011. Fundación Centro de Investigación y Documentación de la Casa-Sociedad Hipotecaria Federal. Available at: http://doc.shf.gob.mx/English/Press/ Publications/Documents/EAVM\%20INGLES\%20 2011.pdf (last accessed on June 15, 2019).

Coles S. 2001. An introduction to statistical modeling of extreme values. 2nd ed. Springer Series in Statistics, London.

Colorado-Ruiz G, Cavazos T, Salinas JA, De Grau P, Ayala R. 2018. Climate change projections from Coupled Model Intercomparison Project phase 5 multi-model weighted ensembles for Mexico, the North American monsoon and the mid-summer drought region. International Journal of Climatology 38: 5699-5716. https:// doi.org/10.1002/joc.5773

Cooley D, Nychka D, Naveau P. 2007. Bayesian spatial modeling of extreme precipitation return levels. Journal of the American Statistical Association 102: 824840. https://doi.org/10.1198/016214506000000780

Coutts MA, Tapper JN, Beringer J, Loughnan M, Demuzere M. 2012. Watering our cities: The capacity for water sensitive urban design to support urban cooling and improve human thermal comfort in the Australian context. Progress in Physical Geography 37: 2-28. https://doi.org/10.1177/0309133312461032

De Munck C, Lemonsu A, Masson V, Le Bras J, Bonhomme M. 2018. Evaluating the impacts of greening scenarios on thermal comfort and energy and water consumptions for adapting Paris city to climate change. Urban Climate 23: 260-286. https://doi.org/10.1016/j. uclim.2017.01.003

Della-Marta MP, Haylock RM, Luterbacher J, Wanner H. 2007. Doubled length of western European summer heat waves since 1880. Journal of Geophysical Research 112: D15103. https://doi.org/10.1029/ 2007JD008510
Dixon P, Ellison A, Gotelli N. 2005. Improving the precision of estimates of the frequency of rare events. Ecology 86: 1114-1123. https://doi.org/10.1890/04-0601

Dumitrescu A, Bojariu R, Birsan M-V, Marin L, Manea A. 2015. Recent climatic changes in Romania from observational data (1961-2013). Theoretical Applied Climatology 122: 111-119. https://doi.org/10.1007/ s00704-014-1290-0

El Adlouni S, Ouarda TBMJ, Zhang X, Roy R, Bobée B. 2007. Generalized maximum likelihood estimators for the nonstationary generalized extreme value model. Water Resources Research 43: W03410. https://doi. org/10.1029/2005WR004545

Easterling DR, Kunkel KE, Wehner MF, Sun L. 2016. Detection and attribution of climate extremes in the observed record. Weather and Climate Extremes 11: 17-27. https://doi.org/10.1016/j.wace.2016.01.001

Fengjin X, Lianchun S. 2011. Analysis of extreme low-temperature events during the warm season in Northeast China. Natural Hazards 58: 1333. https:// doi.org/10.1007/s11069-011-9735-6

Fisher RA, Tippett LHC. 1928. Limiting forms of the frequency distribution of the largest or smallest member of a sample. Proceedings of the Cambridge Philosophical Society 24: 180-190. https:// doi.org/10.1017/ S0305004100015681

Fonseca-Hernández M, Tereshchenko I, Mayor Y, Figueroa-Montaño A, Cuesta-Santos O, Monzón C. 2018. Atmospheric pollution by $\mathrm{PM}_{10}$ and $\mathrm{O}_{3}$ in the Guadalajara metropolitan area, Mexico. Atmosphere 9: 243. https://doi.org/10.3390/atmos9070243

Friederichs P. 2010. Statistical downscaling of extreme precipitation events using extreme value theory. Extremes 13: 109. https://doi.org/10.1007/s10687-010-0107-5

Furió D, Meneu V. 2011. Analysis of extreme temperatures for four sites across Peninsular Spain. Theoretical and Applied Climatology 104: 83-99. https://doi. org/10.1007/s00704-010-0324-5

Gao Y, Fu JS, Drake JB, Liu Y, Lamarque J-F. 2012. Projected changes of extreme weather events in the eastern United States based on a high-resolution climate modeling system. Environmental Research Letters 7: 1-12. https://doi.org/10.1088/1748-9326/7/4/044025

García-Cueto R, Tejeda-Martínez A, Jáuregui E. 2010. Heat waves and heat days in an arid city in the northwest of México: current trends and in climate change scenarios. International Journal of Biometeorology 54: 335-345. https://doi.org/10.1007/s00484-009-0283-7 
García-Cueto OR, Santillán-Soto N, Quintero-Núñez M, Ojeda-Benítez S, Velázquez-Limón N. 2013. Extreme temperature scenarios in Mexicali, México under climate change conditions. Atmósfera 26: 509-520. https://doi.org/10.1016/S0187-6236(13)71092-0

García-Cueto OR, Cavazos T, de Grau P, Santillán-Soto N. 2014. Analysis and modeling of extreme temperatures in several cities in northwestern Mexico under climate change conditions. Theoretical and Applied Climatology 116: 211-225. https://doi.org/10.1007/ s00704-013-0933-x

García-Cueto OR, Santillán-Soto N, López-Velázquez JE, Reyes-López J, Cruz-Sotelo S, Ojeda-Benítez S. 2018. Trends of climate change indices in some Mexican cities from 1980 to 2010. Theoretical and Applied Climatology 137: 775-790. https://doi.org/10.1007/ s00704-018-2620-4

Gilleland E, Katz R. 2005. Extremes toolkit (extRemes): Weather and climate applications of extreme value statistics. Available at: https://www.lmd.jussieu.fr/ li/ atelier_cc/tutorial_extremes.pdf (last accessed on September 20, 2018).

Gilleland E, Katz R. 2006. Analyzing seasonal to interannual extreme weather and climate variability with the extremes toolkit (extRemes). In: 18th Conference on Climate Variability and Change, 86th American Meteorological Society (AMS) Annual Meeting, Atlanta, Georgia, January 29-February 2. Available at: https://ams.confex.com/ams/Annual2006/ techprogram/paper_101830.htm (last accessed on April 15, 2019).

Gilleland E, Katz, RW. 2013. in2extRemes: Into the R Package extRemes extreme value analysis for weather and climate applications. NCAR/TN-523+STR Technical Note. National Center for Atmospheric Research, Boulder, Colorado. Available at: https://opensky.ucar. edu/islandora/object/technotes\%3A534/datastream/ PDF/view (last accessed on May 2, 2019).

Gosling SN, Dunn R, Carrol F, Christidis N, Fullwood J, de Gusmao D, Golding N, Good L, Hall T, Kendon L, Kennedy J, et al. 2011. Climate: Observations, projections and impacts: Mexico. UK Met Office. Nottingham ePrints, Nottingham, UK. Available at: http://www.unscn.org/files/NutCC/Mexico.pdf (last accessed on August 24, 2019).

Grotjahn R, Black R, Leung R, Wehner FM, Barlow M, Bosilovich M, Gershunov A, Gutowski JW, Gyakum RJ, Katz RW, Lee Y-Y, Lim Y-K, Prabhat. 2016. North
American extreme temperature events and related largescale meteorological patterns: A review of statistical methods, dynamics, modeling, and trends. Climate Dynamics 46: 1151-1184. https://doi.org/10.1007/ s00382-015-2638-6

Guan Y, Zhang X, Zheng F, Wang B. 2015. Trends and variability of daily temperature extremes during 1960-2012 in the Yangtze River Basin, China. Global Planetary Change 124: 79-94. https://doi.org/10.1016/j. gloplacha.2014.11.008

Hartmann DL, Klein Tank AMG, Rusticucci M, Alexander LV, Brönnimann S, Charabi, Y, Dentener FJ, Dlugokencky EJ, Easterling DR, Kaplan A, Soden BJ, Thorne PW, Wild M, Zhai PM. 2013. Observations: atmosphere and surface. In: Climate Change 2013: The Physical Science Basis. Contribution of Working Group I to the Fifth Assessment Report of the Intergovernmental Panel on Climate Change (Stocker TF, Qin D, Plattner G-K, Tignor M, Allen SK, Boschung, J, Nauels A, Xia Y, Bex V, Midgley PM, Eds.). Cambridge University Press, Cambridge, United Kingdom and New York, NY, USA.

Hatfield JL, Prueger JH. 2015. Temperature extremes: Effect on plant growth and development. Weather and Climate Extremes 10: 4-10. https://doi.org/10.1016/j. wace.2015.08.001

Heim Jr. RR. 2015. An overview of weather and climate extremes. Weather and Climate Extremes 10: 1-9. https://doi.org/10.1016/j.wace.2015.11.001

Helsel DR, Hirsch MR. 1992. Statistical methods in water resources. Elsevier, New York.

Hernández AR, Galeana GJ, Villegas BI. 2014. La urbanización en México 2010-2030: un esbozo de los retos y oportunidades asociados al crecimiento urbano y regional. En: La situación demográfica de México 2014. Consejo Nacional de Población, México, 139-164.

Houngninou BE, Allé CSU, Kougbéagbédè H, Guédjé KF. 2017. Changes in daily temperature extremes over Benin between 1970 and 2015. International Journal of Advances Research 5: 108-113. https://doi. org/10.21474/IJAR01/5944

IPCC. 2013. Climate change 2013: The physical science basis. Contribution of Working Group I to the Fifth Assessment Report of the Inter-governmental Panel on Climate Change (Stocker TF, Qin D, Plattner G.-K, Tignor M, Allen PM, Boschung J, Nauels A, Xia Y, Bex V, Midgley PM, Eds.). Cambridge University Press, Cambridge, United Kingdom and New York, NY, USA. 
Jain S, Lall U. 2001. Magnitude and timing of annual maximum floods, trends and large-scale climatic associations for the Blacksmith Fork River, Utah. Water Resources Research 36: 3641-3651. https://doi. org/10.1029/2000WR900183

Jentsch A, Kreyling J, Beierkuhnlein C. 2007. A new generation of climate change experiments: Events, not trends. Frontiers in Ecology and the Environment 5: 315-324. https://doi.org/10.1890/1540-9295(2007) 5[365:ANGOCE]2.0.CO;2

Katz R, Parlange M, Naveau P. 2002. Statistics of extremes in hydrology. Advances in Water Resources 25: 1287 1304. https://doi.org/10.1016/S0309-1708(02)00056-8

Katz R, Brush G, Parlange M. 2005. Statistics of extremes: Modeling ecological disturbances. Ecology 86: 11241134. https://doi.org/10.1890/04-0606

Katz RW. 2013. Statistical methods for nonstationary extremes. In: Extremes in changing climate (Aghakouchak A, Easterling D, Hsu K, Schubert S, Sorooshian S, Eds.). Water Science and Technology Library, vol 65, Springer, Dordrecht, 15-37.

Kharin VV, Zwiers FW. 2005. Estimating extremes in transient climate change simulations. Journal of Climate 18: 1156-1173. https://doi.org/10.1175/JCLI3320.1

Koutsoyiannis D. 2004. Statistics of extremes and estimation of extreme rainfall: I. Theoretical investigation/ Statistiques de valeurs extrêmes et estimation de précipitations extrêmes: I. Recherche théorique. Hydrological Sciences Journal 49: 575-590. https://doi. org/10.1623/hysj.49.4.575.54430

Kendall MG. 1975. Rank correlation methods. Charles Graffin, London.

Kim YH, Min SK, Zhang X, Zwiers F, Alexander LV, Donat MG, Tung YS. 2015. Attribution of extreme temperature changes during 1951-2010. Climate Dynamics 46: 1769-1782. https://doi.org/10.1007/ s00382-015-2674-2

Krausmann F, Wiedenhofer D, Lauk Ch, Haas W, Tanikawa H, Fishman T, Miatto A, Schandl H, Haberl H. 2017. Global socioeconomic material stocks rise 23 -fold over the 20th century and require half of annual resource use. PNAS 8: 1880-1885. https://doi. org/10.1073/pnas. 1613773114

Lau N-C, Nath MJ. 2012. A model study of heat waves over North America: Meteorological aspects and projections for the twenty-first century. Journal of Climate 25: 4761-4784. https://doi.org/10.1175/ JCLI-D-11-00575.1
Leclerc M, Ouarda T. 2007. Non-stationary regional flood frequency analysis at ungauged sites. Journal of Hydrology 343: 254-265. https://doi.org/10.1016/j. jhydrol.2007.06.021

Liu G, Zhang L, He B, Jin X, Zhang Q, Razafindrabe B, You H. 2015. Temporal changes in extreme high temperature, heat waves and relevant disasters in Nanjing metropolitan region, China. Natural Hazards 76: 1415. https://doi.org/10.1007/s11069-014-1556-y

Magaña V, Pérez J, Méndez M. 2003. Diagnosis and prognosis of extreme precipitation events in the Mexico City basin. Geofísica Internacional 41: 247-259.

Magaña V, Zermeño D, Neri C. 2012. Climate change scenarios and potential impacts on water availability in northern Mexico. Climate Research 51: 171-184. https://doi.org/10.3354/cr01080

Mann HB. 1945. Nonparametric tests against trend. Econometrica 13: 245-259. https://doi.org/00129682(194507)13:3<245:NTAT>2.0.CO;2-U p. 245-259.

Martínez-Austria PF, Bandala ER. 2017. Temperature and heat-related mortality trends in the Sonoran and Mojave Desert region. Atmosphere 8. https://doi. org/10.3390/atmos8030053

Matsueda S, Takaya Y. 2015. The global influence of the Madden-Julian Oscillation on extreme temperature events. Journal of Climate 28: 4141-4151. https://doi. org/10.1175/JCLI-D-14-00625.1

Meehl G, Karl T, Easterling RD, Changnon S, Pielke R Jr., Changnon D, Evans J, Groisman YP, Knutson RT, Kunkel EK, Mearns OL, Parmesan C, Pulwarty R, Root T, Sylves TR, Whetton P, Zwiers F. 2000. An introduction to trends in extreme weather and climate events: Observations, socioeconomic impacts, terrestrial ecological impacts, and model projections. Bulletin American of the Meteorological Society 81: 413-416. https://doi.org/10.1175/1520-0477(2000)081<0413: AITTIE $>2.3 . \mathrm{CO} ; 2$

Meehl G, Tebaldi C. 2004. More intense, more frequent, and longer lasting heat waves in the twenty-first century. Science 305: 994-997. https://doi.org/10.1126/ science. 1098704

Milly PCD, Betancourt J, Falkenmark M, Hirsch M, Kundzewicz ZW, Lettenmaier DP, Stouffer RJ. 2008. Stationarity is dead: Whither water management? Science 319: 573-574. https://doi.org/10.11267/science. 1151915

Miralles DG, Teuling AJ, van Heerwaarden CC, de Arellano JVG. 2014. Mega-heatwave temperatures due 
to combined soil desiccation and atmospheric heat accumulation. Nature Geoscience 7: 345-349. https:// doi.org/10.1038/NGEO2141

Mondal A, Mujumdar PP. 2015. Modeling non-stationarity in intensity, duration and frequency of extreme rainfall over India. Journal of Hydrology 521: 217-231. https:// doi.org/101016/j.jhydrol.2014.11.071

Moritz AM. 1997. Analyzing extreme disturbance events: Fire in Los Padres National Forest. Ecological Applications 7: 1252-1262. https://doi.org/10.1890/1051-0 761(1997)007[1252:AEDEFI]2.0.CO;2

Mugume I, Shen S, Tao S, Mujuni G. 2016. Analysis of temperature variability over desert and urban areas of northern China. Climatology and Weather Forecasting 4: 162. https://doi.org/10.4172/2332-2594.1000162

Ongoma V, Chen H, Omony GW. 2016. Variability of extreme weather events over the equatorial East Africa, a case study of rainfall in Kenya and Uganda. Theoretical and Applied Climatology 131: 295-308. https://doi. org/10.1007/s00704-016-1973-9

Palmer T, Räisänen J. 2002. Quantifying the risk of extreme seasonal precipitation events in a changing climate. Nature 415: 512-514. https://doi.org/10.1038/415512a

Panagoulia D, Economou P, Caroni C. 2013. Stationary and nonstationary generalized extreme value modelling of extreme precipitation over a mountainous area under climate change. Environmetrics 25: 29-43. https://doi. org/10.1002/env.2252

Papalexiou SM, Koutsoyiannis D. 2013. Battle of extreme value distributions: A global survey on extreme daily rainfall. Water Resources Research 49: 187-201. https://doi.org/10.1029/2012WR012557

Parey S, Malek F, Laurent C, Dacunha-Castelle D. 2007. Trends and climate evolution: Statistical approach for very high temperatures in France. Climatic Change 81: 331-352. https://doi.org/10.1007/s10584-006-9116-4

Parey S, Hoang TTH, Dacunha-Castelle D. 2018. Future high-temperature extremes and stationarity. Natural Hazards 98: 1115.1134. https://doi.org/10.1007/ s11069-018-3499-1

Parker TJ, Berry GJ, Reeder MJ, Nicholls N. 2014. Modes of climate variability and heat waves in Victoria, southeastern Australia. Geophysical Research Letters 41: 6926-6934. https://doi.org/10.1002/2014GL061736

Qiang Z, Vijay PS, Suna P, Chend X. 2011. Precipitation and stream flow changes in China: Changing patterns, causes and implications. Journal of Hydrology 410: 204-216. https://doi.org/10.1016/j.jhydrol.2011.09.017
Renardt B, Sun X, Lang M. 2013. Bayesian methods for non-stationary extreme value analysis. In: Extremes in a changing climate (AghaKouchak A, Easterling D, Hsu K, Schubert S, Sorooshian S, Eds.). Water Science and Technology Library, vol. 65, Springer, Dordrecht, 39-95.

Raggad B. 2018. Statistical assessment of changes in extreme maximum temperatures over Saudi Arabia, 1985-2014. Theoretical and Applied Climatology 132: 1217-1235. https://doi.org/10.1007/s00704-0172155-0

Ríos-Alejandro JG. 2011. Temperaturas extremas en la ciudad de Monterrey, N.L., México. Revista Chapingo Serie Ciencias Forestales y del Ambiente 17: 225-230. https://doi.org/10.5154/r.rchscfa.2010.06.036

Rosenzweig C, Solecki W, Hammer SA, Mehrotra S. 2011. Climate change and cities: First assessment report of the Urban Climate Change Research Network. Cambridge University Press, Cambridge, MA.

Salmi T, Maata A, Antilla P, Ruoho-Airola T, Amnell T. 2002. Detecting trends of annual values of atmospheric pollutants by the Mann-Kendall test and Sen's slope estimates - The excel template application Makesens. Finnish Meteorological Institute, Helsinki. Available at: https://www.researchgate. net/publication/259356944 (last accessed on May 15, 2019).

Schoof TJ, Robeson MS. 2016. Projecting changes in regional temperature and precipitation extremes in the United States. Weather and Climate Extremes 11: 28-40. https://doi.org/10.1016/j.wace.2015.09.004

Sen PK. 1968. Estimates of the regression coefficient based on Kendall's tau. Journal of the American Statistical Association 63: 1379-1389. https://doi.org/10.1080/0 1621459.1968.10480934

Seneviratne SI, Nicholls N, Easterling D, Goodess CM, Kanae S, Kossin J, Luo Y, Marengo J, McInnes K, Rahimi M, Reichstein M, Sorteberg A, Vera C, Zhang X. 2012. Changes in climate extremes and their impacts on the natural physical environment. In: Managing the risks of extreme events and disasters to advance climate change adaptation. A special report of Working Groups I and II of the Intergovernmental Panel on Climate Change (Field CB, Barros V, Stocker TF, Qin D, Dokken DJ, Ebi KL, Mastrandrea MD, Mach KJ, Plattner G-K, Allen SK, Tignor M, Midgley PM, Eds.). Cambridge University Press, Cambridge, United Kingdom and New York, NY, USA. 
Shen L, Mickley JL, Gilleland E. 2016. Impact of increasing heat waves on U.S. ozone episodes in the 2050s: Results from a multimodel analysis using extreme value theory. Geophysical Research Letters 43: 4017 4025. https://doi.org/10.1002/ 2016GL068432

Skelhorn CP, Lindley S, Levermore G. 2018. Urban greening and the UHI: Seasonal trade-offs in heating and cooling energy consumption in Manchester, UK. Urban Climate 23: 173-187. https://doi.org/10.1016/j. uclim.2017.02.010

Smith R. 2001. Environmental statistics. Department of Statistics, University of North Carolina, USA. Available at: http://www.stat.unc.edu/postscript/rs/envnotes. ps (last accessed on May 30, 2019).

Song X, Zhang Z, Chen Y, Wang P, Xiang M, Shi P, Tao F. 2014. Spatiotemporal changes of global extreme temperature events (ETEs) since 1981 and the meteorological causes. Natural Hazards 70: 975. https://doi. org/10.1007/s11069-013-0856-y

Tabari H, Marofi S, Ahmadi M. 2011. Long-term variations of water quality parameters in the Maroon River, Iran. Environmental Monitoring and Assessment 177: 273-287. https://doi.org/10.1007/s10661-010-1633-y

Tanarhte M, Hadjinicolaou P, Lelieveld J. 2015. Heat wave characteristics in the eastern Mediterranean and Middle East using extreme value theory. Climate Research 63: 99-113. https://doi.org/10.3354/cr01285

Taxak KA, Murumkar AR, Arya DS. 2014. Long term spatial and temporal rainfall trends analysis in Wainganga basin, Central India. Weather and Climate Extremes 4: 50-61. https://doi.org/10.1016/j.wace.2014.04.005

Taylor KE, Stouffer RJ, Meehl GA. 2012. An overview of CMIP5 and the experimental design. Bulletin of the American Meteorological Society 93, 4: 485-498. https://doi.org/10.1175/BAMS-D-11-00094.1

Thiombiano AN, El Adlouni S, St-Hilaire A, Ouarda T, El-Jaabi N. 2017. Nonstationary frequency analysis of extreme daily precipitation amounts in Southeastern Canada using a peaks-over-threshold. Theoretical and Applied Climatology 129: 413-426. https://doi. org/10.1007/s00704-016-1789-7

Trenberth KE, Jones PD, Ambenje P, Bojariu R, Easterling D, Klein Tank A, Parker D, Rahimzadeh F, Renwick JA, Rusticucci M, Soden B, Zhai P. 2007. Observations: surface and atmospheric climate change. In: Climate Change 2007: The Physical Science Basis. Contribution of Working Group I to the Fourth
Assessment Report of the Intergovernmental Panel on Climate Change (Solomon S, Qin D, Manning M, Chen Z, Marquis M, Averyt KB, Tignor M, Miller HL, Eds.). Cambridge University Press, Cambridge, United Kingdom and New York, NY, USA.

Ummenhofer CC, Meehl GA. 2017. Extreme weather and climate events with ecological relevance: a review. Philosophical Transactions of the Royal Society B 372: 20160135. http://doi.org/10.1098/rstb.2016.0135 UN-Habitat. 2011. Cities and climate change: Global report on human settlements. Earthscan, London, Washington DC. Available at: https://unhabitat.org/ global-report-on-human-settlements-2011-cities-andclimate-change (accessed on May 5, 2019).

Wang H, Chen Y, Chen Z, Li W. 2013. Changes in annual and seasonal temperature extremes in the arid region of China, 1960-2010. Natural Hazards 65: 1913. https:// doi.org/10.1007/s11069-012-0454-4

Wang XL, Feng Y. 2010. RHtestsV3 user manual. Climate Research Division, Environment Canada, Toronto, Canada, 24 pp. Available at: http://groupware.sinanet. isprambiente.it/scidip/library/ts-homogeneization_repinfo/r-scritp-user-manual/download/1/RHtestsV3_ UserManual.pdf (last accessed on June 10, 2019).

Wang Z-H, Zhao X, Yang J, Song J. 2016. Cooling and energy saving potentials of shade trees and urban lawns in a desert city. Applied Energy 161: 437-444. https:// doi.org/10.1016/j.apenergy.2015.10.047

Waylen PR, Keellings D, Qiu Y. 2012. Climate and health in Florida: Changes in risks of annual maximum temperatures in the second half of the twentieth century. Applied Geography 33: 73-81. https://doi. org/10.1016/j.apgeog.2011.06.007

Whan K, Zscheischler J, Orth R, Shongwe M, Rahimi M, Asare E, Seneviratne S. 2015. Impact of soil moisture on extreme maximum temperatures. Weather and Climate Extremes 9: 57-67. https://dx.doi.org/10.1016/j. wace.2015.05.001

Wypych A, Sulikowska A, Ustrnul Z, Czekierda D. 2017. Temporal variability of summer temperature extremes in Poland. Atmosphere 8: 51. https://doi.org/10.3390/ atmos 8030051

Zhang X, Yang F. 2004. RClimDex (1.0) user manual. Climate Research Branch, Environment Canada, 22 pp. Available at: https://acmad.net/rcc/procedure/ RClimDexUserManual.pdf (last accessed on June 2, 2019). 